\title{
A Comparison of Vocabulary Items for the Eighth Grade English Coursebooks in
} Turkey* $^{*}$

\author{
Abdurrahman GÜDÜCÜ ${ }^{* *}$ Fatih GÜNGÖR ${ }^{* * *}$
}

- Received: 21.09.2020 • Accepted: 23.06.2021 • Online First: 02.11.2021

\begin{abstract}
This study aims to analyze vocabulary items in the eighth grade English coursebooks used in Turkey and to compare their frequencies with the Common European Framework of Reference for Languages (CEFR), British National Corpus (BNC), Corpus of Contemporary American English (COCA), and Academic Word List (AWL). Additionally, we extracted the most frequent 50 verbs, adjectives, and adverbs. The results revealed that the most frequent verbs were $d o$, is are; the most frequent adjectives were correct, short, natural, great, good, new, social, first, favorite and the most frequent adverbs were then, really, there, here, very, always, too, well, more, usually and often. Touchstone 2 mostly corresponded to the CEFR A2 level, BNC's and COCA's first 2000 lists, while others had less satisfactory inclusion percentages. When we compared the coursebooks with AWL, Upswing English had the highest inclusion percentages. Although Touchstone 2 seems to have the highest inclusion percentages, all coursebooks should consider this study's results to revise their vocabulary selection.
\end{abstract}

Keywords: vocabulary items, word frequency, coursebooks, corpus-based study.

\section{Cited:}

Güdücü, A., \& Güngör, F. (2022). A comparison of vocabulary items for the eighth grade English coursebooks in Turkey. Pamukkale University Journal of Education, 54, 130-157.doi: 10.9779/ pauefd.798049.

\footnotetext{
* This study was a product of the first author's master thesis "A comparison of vocabulary items in eighth grade English coursebooks" under the supervision of the second author.

** Teacher, Ministry of National Education in Turkey, ORCID ID: 0000-0003-4072-5009, abdrrhmngdc@gmail.com

*** Asst. Prof. Dr., Afyon Kocatepe University, ORCID ID: 0000-0002-0800-4212, fgungor@aku.edu.tr
} 


\section{Introduction}

English as a foreign language (EFL) textbooks are major input source for students to learn vocabulary items (Jordan \& Gray, 2019). Especially in the countries (e.g., Turkey) where the mother tongue is not English, and the chance to use the target language in daily life is low, coursebooks constitute the primary source for effective language teaching (Kayaoğlu, 2011). The exposure time to the target language is limited to school and class in language learning process in Turkey (Suna \& Durmuşçelebi, 2013). Thus, the content provided by coursebooks is essential for students to learn a language. Therefore, coursebooks have an important place due to their extensive use in language teaching (Turanl, 2004), and it is necessary to aptly select the vocabulary items that have the utmost importance for students (Sun \& Dang, 2020).

When we analyze the previous studies in the world, most of them focused on primary school coursebooks (Alcaraz, 2009; Alexiou \& Konstantakis, 2009; Kim, 2002; Nordlund \& Norberg, 2020), middle school coursebooks (Catalan \& Francisco, 2008; Kitao \& Tanaka, 2009) and university coursebooks (Hajiyeva, 2015). The studies in the Turkish context analyzed an $8^{\text {th }}$-grade coursebook (Ünlü, 2012), compared 11 books with Touchstone I (Çinar, 2015) and A2 books with CEFR (Baydal, 2016). The current study differs from the previous studies in terms of the grade ( $8^{\text {th }}$ grade), level of the textbook (A2 level), corpus, and word lists (COCA, BNC, AWL, and EVP). Compared to the previous studies, since relatively few studies examine and compare English coursebooks based on a corpus, this study is expected to contribute to the English language teaching field by presenting some implications on vocabulary selection to curriculum and materials designers, teachers, and students.

\section{Theorirical Background}

\section{Language Education and Coursebooks}

Since coursebooks, as frequently used resources in language teaching, play a role in showing the curriculum's objectives (Sheldon, 1988), learners grasp most of the vocabulary items from coursebooks (Cao, 2018; Cunningsworth, 1995; Kirana, Basthami, Isnawati \& Fitriani, 2018; Nordlund, 2016). This reveals the fact that while choosing the words, coursebooks should meet individuals' needs. However, the coursebooks in Turkey do not define an explicit criterion for choosing vocabulary items but just give a list of vocabulary items at the end of the units, including a few words to be learned (Baydal, 2016). Hence, the authors of 
coursebooks have to consider some criteria while choosing words. Although there are many words in a language, not all are equally useful (Nation \& Waring, 1997). Then, there are some questions in our minds like "Which words should we teach to learners?, What words should coursebooks contain?, How much vocabulary should learners have?". Indeed, it is not expected that an average foreign language student has the vocabulary size of native speakers (Alcaraz, 2009). Therefore, we need to focus on vocabulary size and word frequency (Nunan, 1991).

Vocabulary knowledge is considered an important component of language learning (Guan, 2013), and this knowledge directly affects reading and writing skills (Nation \& Waring, 1997). Frequency is the first parameter in vocabulary selection because learners become familiar with the most frequent words and do not have difficulty in comprehension (Alhudithi, 2017). In other words, what is more frequent refers to the needs of language learners (Leech, 2011; Zimmerman and Schmitt, 2005). The second parameter is vocabulary size. The threshold of vocabulary size required for daily life situations is 2000 words (Jahan, Mahmood, \& Azhar, 2019; O'Keeffe, McCarthy, \& Carter, 2007; Thornbury, 2002), and learning high frequent first 2000 words improves students' listening comprehension and reading skills and thus improves students' language learning. We can suggest that it is functional to use the most frequent 1000 or 2000 words based on the results of corpus studies. Therefore, it is necessary to focus on the most frequent 2000 words in A2 level books.

\section{Corpus Use and Data-Driven Learning in Language Education}

Corpus data started to shape the word choices in coursebooks in the world, and Data-Driven Learning applications (hereafter DDL), direct applications of the corpus into language teaching as Wahid (2011) refers to, help learners to identify the place of words in authentic texts and to observe their context (Guan, 2013). To adopt DDL into language methodology, Gilquin and Granger (2010, p. 360) propose two resources: "a corpus and a tool to exploit the corpus (concordancing software)." Therefore, with the help of technology, by bringing corpora into the classroom, a great variety of authentic examples will be presented to learners to teach a language.

In Turkey's 2023 Education Vision document, language teaching should be supported by online and mobile technologies, and foreign language teaching will be studentoriented by selecting the most appropriate methods for students (MoNE, 2018b). The use of technology and the student-oriented approach mentioned in the 2023 Education Vision 
document are also valid for DDL practices. For instance, students may interact with a corpus and do queries alone (McEnery \& Wilson, 1997), or a corpus can be used for designing materials and curriculum, and in-class activities for learning vocabulary and grammar (Johansson, 2009).

As one of the curriculum types, the lexical syllabus is a corpus-based design (Hunston, 2002), and such a syllabus is expected to include the most frequent vocabulary forms, examples of uses, and combinations of words (Sinclair \& Renouf, 1988). In other words, a corpus-based curriculum is more than the school-English (Mindt, 1996). Furthermore, a corpus is a tool for teaching and learning, and assessment (McEnery \& Xiao, 2011).

\section{Aim of the Study}

Considering the significance of vocabulary knowledge and its relationship with corpus, we aim to analyze vocabulary frequency and vocabulary level of the coursebooks Upswing English, Mastermind, More \& More, Marathon Plus, and Touchstone 2 based on British National Corpus (BNC), Contemporary Corpus of American English (COCA), Academic Word List (AWL), and Common European Framework of Reference for Languages (hereafter CEFR). The first two coursebooks were used in Turkish public schools in the 2019-2020 academic years. The consecutive two coursebooks could be used interchangeably in Turkish state and private schools in previous years. The last one claims to be a corpusbased coursebook. For this purpose, we aim to determine the extent to which the vocabulary in the corpora of selected coursebooks is among the target vocabulary used primarily in English teaching and learning. At the same time, this study will give some suggestions and implications for the language teaching field by referring to the DDL and 2023 Education Vision document. Hence, we attempted to answer the following questions:

1. What are the most frequent 50 verbs, adjectives, and adverbs in the selected coursebooks?

2. At what levels are the words in the corpora of selected coursebooks in the CEFR according to English Vocabulary Profile (EVP)?

3. To what extent do the most frequent words in the selected coursebooks include the vocabulary items covered in BNC, COCA, and AWL? 


\section{Method}

This study is a corpus-based one. According to McEnery and Hardie (2012, p. 6), corpus data in corpus-based studies are used "in order to explore a theory or hypothesis, typically one established in the current literature, in order to validate it, refute it or refine it". Corpusbased studies are studies in which a specific structure or a function is analyzed within the frame of a theory or a hypothesis (Güngör, 2016). In this sense, this study is a corpus-based study since the frequency information of the vocabulary in the selected coursebooks is examined within the frame of reference corpora.

\section{Data Collection Process and Data Analysis}

In this study, besides the coursebooks Upswing English and Mastermind, distributed free of charge by MoNE to the public schools in the 2019-2020 academic years, we examined the coursebooks More \& More and Marathon Plus, written by Turkish authors and published by private publishers. Furthermore, Touchstone 2, a corpus-based book published by native English authors and an international publisher, was also included in the study. The corpora of these coursebooks were analyzed by using AntConc (Anthony, 2019) software. After the analysis, we transferred the frequency information to Excel files and formed the frequency lists. Using these lists, we created a list of the most frequent 50 verbs, adjectives, and adverbs through an online analysis tool called Textinspector (WebLingua) and evaluated these words in accordance with CEFR, BNC, COCA, and AWL. The "Tagger" function in Textinspector (WebLingua) was used to determine the lists of the most frequent 50 words. The results of Tagger were classified as verbs, adjectives, and adverbs in Excel files. Due to the lack of frequency information in these Tagger lists, the verbs, adjectives and adverbs in these lists were searched one by one in the frequency lists, and their frequency information was noted. Next, the words in these lists were checked one by one by using concordance function on AntConc (Anthony, 2019). The purpose of this was to determine how many times the words in the verb, adjective and adverb frequency lists were used as verb, adjective and adverb in the coursebooks and to determine whether this information corresponds to the information in the frequency list.

\section{Results}

We extracted the most frequent 50 verbs, adjectives, and adverbs in the coursebooks to see the overall picture and compared vocabulary frequencies with CEFR, BNC, COCA, and AWL. 
A. Güdücü, \& F. Güngör / Pamukkale University Journal of Education, 54, 130-157, 2022

The Most Frequent 50 Verbs, Adjectives, and Adverbs in Eighth Grade Coursebooks

We formed lists for the most frequent 50 verbs, adjectives, and adverbs lists. Accordingly, Table 1 shows the most frequent 50 verbs, adjectives, and adverbs used in Upswing English.

Table 1. The most frequent verbs, adjectives, and adverbs in Upswing English

\begin{tabular}{|c|c|c|c|c|c|}
\hline Verb & $f$ & Adjective & $f$ & Adverb & $f$ \\
\hline do & 296 & natural & 47 & then & 88 \\
\hline is & 246 & social & 46 & there & 73 \\
\hline are & 164 & great & 35 & very & 53 \\
\hline have & 140 & short & 33 & always & 39 \\
\hline like & 113 & correct & 32 & usually & 39 \\
\hline write & 103 & good & 27 & most & 33 \\
\hline use & 101 & different & 27 & first & 32 \\
\hline read & 93 & interesting & 26 & often & 30 \\
\hline go & 75 & favorite & 25 & also & 29 \\
\hline make & 72 & possible & 24 & well & 27 \\
\hline take & 68 & first & 22 & again & 27 \\
\hline work & 63 & teen & 21 & about & 26 \\
\hline does & 61 & other & 20 & sometimes & 22 \\
\hline listen & 61 & old & 18 & too & 22 \\
\hline see & 56 & long & 17 & now & 21 \\
\hline be & 52 & popular & 17 & finally & 18 \\
\hline give & 50 & related & 15 & together & 18 \\
\hline think & 50 & necessary & 14 & so & 16 \\
\hline prefer & 49 & better & 14 & rather & 16 \\
\hline love & 47 & online & 13 & ever & 14 \\
\hline did & 42 & new & 13 & never & 14 \\
\hline help & 40 & bad & 12 & really & 14 \\
\hline get & 40 & dangerous & 12 & today & 11 \\
\hline was & 40 & high & 12 & here & 11 \\
\hline ask & 38 & main & 12 & probably & 11 \\
\hline doing & 36 & responsible & 12 & yet & 10 \\
\hline follow & 33 & daily & 11 & all & 9 \\
\hline
\end{tabular}




\begin{tabular}{|c|c|c|c|c|}
\hline match & 32 & important & 11 & else \\
\hline has & 32 & large & 11 & just \\
\hline talk & 31 & traditional & 11 & as \\
\hline complete & 28 & human & 10 & much \\
\hline want & 26 & false & 10 & alone \\
\hline look & 24 & historic & 10 & soon \\
\hline know & 23 & interested & 10 & later \\
\hline understand & 23 & international & 10 & sure \\
\hline buy & 22 & scientific & 10 & tomorrow \\
\hline prepare & 22 & last & 9 & even \\
\hline going & 22 & cultural & 9 & exactly \\
\hline $\mathrm{am}$ & 21 & exciting & 9 & ago \\
\hline need & 20 & refundable & 9 & almost \\
\hline tick & 19 & few & 8 & definitely \\
\hline shopping & 19 & adventurous & 8 & effectively \\
\hline come & 18 & common & 8 & regularly \\
\hline find & 18 & entertaining & 8 & approximately \\
\hline choose & 17 & famous & 8 & especially \\
\hline invented & 17 & simple & 8 & everywhere \\
\hline learn & 17 & Turkish & 8 & fairly \\
\hline put & 17 & sure & 7 & firmly \\
\hline mean & 16 & active & 7 & rarely \\
\hline search & 15 & afraid & 7 & enough \\
\hline
\end{tabular}

Table 1 shows the verb $d o(f=296)$ as the most frequent verb in Upswing English. The verbs is $(f=246)$, are $(f=164)$, have $(f=140)$ and like $(f=113)$ were among the most frequent verbs. The adjective natural $(f=47)$ took the first place among the most frequent adjectives. This adjective was followed by social $(f=46)$, great $(f=35)$, short $(f=33)$. The most frequent adverb was then $(f=88)$. Other frequent adverbs are there $(f=73)$, very $(f=53)$, always $(f=$ $39)$ and usually $(f=39)$. 
A. Güdücü, \& F. Güngör / Pamukkale University Journal of Education, 54, 130-157, 2022

Table 2. The most frequent verbs, adjectives, and adverbs in Touchstone 2

\begin{tabular}{|c|c|c|c|c|c|}
\hline Verb & $f$ & Adjective & $f$ & Adverb & $f$ \\
\hline do & 525 & good & 124 & then & 143 \\
\hline are & 358 & new & 95 & really & 111 \\
\hline is & 280 & free & 73 & too & 77 \\
\hline have & 230 & different & 49 & here & 74 \\
\hline was & 167 & next & 46 & just & 69 \\
\hline go & 160 & long & 44 & now & 66 \\
\hline going & 155 & own & 40 & actually & 43 \\
\hline like & 154 & bad & 38 & very & 41 \\
\hline use & 150 & great & 34 & more & 31 \\
\hline get & 149 & sure & 33 & again & 28 \\
\hline listen & 149 & other & 30 & often & 28 \\
\hline take & 106 & first & 28 & maybe & 27 \\
\hline did & 105 & favorite & 28 & always & 26 \\
\hline be & 104 & interesting & 28 & never & 25 \\
\hline think & 103 & best & 27 & also & 21 \\
\hline make & 96 & true & 27 & so & 20 \\
\hline complete & 91 & last & 26 & ever & 20 \\
\hline say & 82 & short & 26 & usually & 20 \\
\hline look & 82 & old & 25 & probably & 19 \\
\hline know & 79 & special & 25 & together & 17 \\
\hline ask & 75 & simple & 25 & away & 16 \\
\hline see & 75 & better & 24 & well & 15 \\
\hline talk & 74 & sorry & 23 & back & 15 \\
\hline find & 69 & nice & 22 & else & 15 \\
\hline want & 65 & interested & 21 & today & 14 \\
\hline write & 64 & top & 19 & almost & 14 \\
\hline were & 62 & big & 18 & sure & 12 \\
\hline practice & 61 & same & 17 & ago & 12 \\
\hline mean & 59 & regular & 17 & still & 12 \\
\hline does & 55 & few & 16 & less & 12 \\
\hline read & 51 & able & 16 & anyway & 11 \\
\hline
\end{tabular}




\begin{tabular}{|c|c|c|c|c|c|}
\hline tell & 51 & false & 16 & naturally & 11 \\
\hline has & 50 & tall & 16 & sometime & 11 \\
\hline learn & 48 & correct & 14 & sometimes & 11 \\
\hline got & 47 & easy & 14 & even & 10 \\
\hline need & 47 & expensive & 14 & tomorrow & 10 \\
\hline give & 45 & hard & 13 & pretty & 10 \\
\hline check & 44 & cold & 12 & that & 8 \\
\hline guess & 43 & funny & 12 & ahead & 8 \\
\hline answer & 41 & happy & 12 & exactly & 8 \\
\hline compare & 39 & ready & 12 & soon & 7 \\
\hline remember & 39 & late & 11 & already & 6 \\
\hline choose & 37 & hot & 11 & anywhere & 6 \\
\hline love & 35 & sick & 11 & alike & 5 \\
\hline play & 34 & young & 11 & definitely & 5 \\
\hline speaking & 33 & Chinese & 10 & especially & 5 \\
\hline talking & 32 & busy & 10 & finally & 5 \\
\hline call & 31 & curly & 10 & everywhere & 4 \\
\hline doing & 31 & main & 10 & far & 4 \\
\hline watch & 30 & tired & 10 & generally & 4 \\
\hline
\end{tabular}

As Table 2 shows, the most frequent verb is $d o(f=525)$ in Touchstone 2. It was followed by are $(f=358)$, is $(f=280)$, have $(f=230)$ and was $(f=167)$. The most frequent adjectives were good $(f=124)$, new $(f=95)$, free $(f=73)$, different $(f=49)$ and next $(f=46)$. The most frequent adverb was then $(f=143)$ and it is followed by really $(f=111)$, too $(f=77)$, here $(f=74)$ and just $(f=69)$.

Table 3. The most frequent verbs, adjectives and adverbs in Mastermind

\begin{tabular}{llllll}
\hline Verb & $\boldsymbol{f}$ & Adjective & $\boldsymbol{f}$ & Adverb & $\boldsymbol{f}$ \\
\hline is & 284 & simple & 50 & there & 71 \\
do & 175 & short & 32 & well & 67 \\
are & 150 & correct & 31 & out & 44 \\
read & 83 & visual & 27 & very & 33 \\
have & 78 & scientific & 26 & again & 31 \\
like & 74 & natural & 24 & then & 27
\end{tabular}


A. Güdücü, \& F. Güngör / Pamukkale University Journal of Education, 54, 130-157, 2022

\begin{tabular}{|c|c|c|c|c|}
\hline write & 58 & new & 24 & more \\
\hline prefer & 46 & first & 23 & also \\
\hline share & 46 & extra & 23 & most \\
\hline match & 44 & responsible & 22 & always \\
\hline be & 42 & online & 21 & now \\
\hline doing & 39 & great & 21 & usually \\
\hline go & 39 & favorite & 21 & often \\
\hline think & 39 & Turkish & 18 & moreover \\
\hline was & 38 & extreme & 18 & finally \\
\hline put & 37 & true & 16 & really \\
\hline listen & 36 & fascinating & 13 & currently \\
\hline work & 33 & best & 12 & generally \\
\hline get & 33 & busy & 11 & mostly \\
\hline understand & 33 & famous & 11 & daily \\
\hline making & 30 & global & 11 & too \\
\hline has & 29 & good & 11 & tomorrow \\
\hline find & 28 & historic & 11 & about \\
\hline keep & 28 & important & 11 & never \\
\hline does & 27 & main & 11 & sometimes \\
\hline add & 26 & old & 11 & today \\
\hline going & 25 & regular & 11 & together \\
\hline make & 25 & appropriate & 10 & so \\
\hline cooking & 24 & sorry & 10 & ever \\
\hline study & 23 & bad & 9 & nearly \\
\hline fill & 23 & national & 9 & rather \\
\hline answer & 22 & daily & 9 & soon \\
\hline giving & 22 & destructive & 8 & firstly \\
\hline reading & 22 & different & 8 & forever \\
\hline want & 22 & easy & 8 & here \\
\hline following & 21 & false & 8 & later \\
\hline spoken & 21 & fond & 8 & regularly \\
\hline did & 20 & inclusive & 8 & abroad \\
\hline expressing & 20 & oral & 8 & away \\
\hline
\end{tabular}




\begin{tabular}{llllll} 
prepare & 20 & related & 8 & individually & 3 \\
take & 20 & easier & 8 & just & 3 \\
use & 20 & other & 7 & continuously & 2 \\
using & 20 & specific & 7 & definitely & 2 \\
likes & 20 & sure & 6 & early & 2 \\
complete & 19 & amusing & 6 & easily & 2 \\
mean & 19 & ancient & 6 & especially & 2 \\
express & 18 & awesome & 6 & exactly & 2 \\
including & 18 & exciting & 6 & internationally & 2 \\
look & 17 & free & 6 & irresponsibly & 2 \\
accepting & 16 & healthy & 6 & periodically & 2 \\
\hline
\end{tabular}

Table 3 indicates that the verb is $(f=284)$ takes the first place in Mastermind. It was followed by $d o(f=175)$, are $(f=150)$, read $(f=83)$ and have $(f=78)$. The most frequent adjectives were simple $(f=50)$, short $(f=32)$, correct $(f=31)$, visual $(f=27)$ and scientific $(\mathrm{f}=$ 26). While there $(f=71)$ was the most frequent adverb, well $(f=67)$, the other frequent adverbs were very $(f=33)$, again $(f=31)$ and then $(f=27)$.

Table 4. The most frequent verbs, adjectives, and adverbs in More\&More

\begin{tabular}{llllll}
\hline Verb & $\boldsymbol{f}$ & Adjective & $\boldsymbol{f}$ & Adverb & $\boldsymbol{f}$ \\
\hline is & 510 & correct & 67 & there & 85 \\
do & 366 & great & 66 & usually & 85 \\
have & 248 & best & 51 & always & 69 \\
are & 206 & new & 49 & more & 60 \\
like & 152 & good & 41 & most & 55 \\
go & 120 & social & 41 & very & 53 \\
be & 114 & other & 40 & too & 48 \\
prefer & 110 & first & 35 & now & 39 \\
think & 109 & important & 35 & often & 39 \\
read & 104 & online & 34 & also & 35 \\
was & 99 & exciting & 30 & really & 34 \\
use & 74 & true & 29 & tomorrow & 33 \\
has & 73 & favorite & 28 & rather & 31 \\
want & 71 & afraid & 28 & ever & 29
\end{tabular}


A. Güdücü, \& F. Güngör / Pamukkale University Journal of Education, 54, 130-157, 2022

\begin{tabular}{|c|c|c|c|c|}
\hline love & 70 & extreme & 27 & never \\
\hline take & 68 & popular & 27 & then \\
\hline make & 64 & last & 25 & first \\
\hline does & 61 & false & 24 & again \\
\hline see & 60 & hot & 24 & sometimes \\
\hline write & 58 & different & 21 & as \\
\hline get & 57 & free & 20 & about \\
\hline help & 55 & possible & 20 & together \\
\hline going & 52 & big & 19 & well \\
\hline join & 49 & old & 19 & soon \\
\hline match & 46 & better & 18 & finally \\
\hline doing & 42 & natural & 18 & still \\
\hline put & 42 & responsible & 18 & so \\
\hline fill & 40 & dangerous & 17 & much \\
\hline did & 39 & famous & 17 & today \\
\hline complete & 38 & delicious & 16 & rarely \\
\hline try & 36 & cultural & 15 & yesterday \\
\hline following & 35 & entertaining & 15 & alone \\
\hline need & 33 & ancient & 14 & lot \\
\hline share & 33 & beautiful & 14 & only \\
\hline say & 32 & classical & 14 & else \\
\hline leave & 31 & interested & 14 & later \\
\hline buy & 31 & past & 13 & mostly \\
\hline look & 31 & busy & 13 & regularly \\
\hline shopping & 31 & cool & 13 & down \\
\hline watch & 31 & large & 13 & currently \\
\hline add & 29 & scientific & 13 & definitely \\
\hline visit & 29 & favourite & 12 & far \\
\hline cook & 28 & historic & 12 & just \\
\hline am & 27 & nice & 12 & abroad \\
\hline come & 27 & traditional & 12 & away \\
\hline feel & 27 & next & 11 & generally \\
\hline shows & 27 & sorry & 11 & here \\
\hline
\end{tabular}


mean

black

11

nowadays

wants

26

available

11

probably

4

been

25

easy

11

slowly

4

Table 4 shows that $i s(f=510)$ is the most frequent verb in More \& More. When the frequency information was considered, do $(f=366)$, have $(f=248)$, are $(f=206)$ and like $(f=$ 152) were among the most frequent verbs. Correct $(f=67)$, great $(f=66)$, best $(f=51)$ and new $(f=49)$ were the most frequent adjectives. There $(f=85)$ was the most frequent adverb in More \& More. It was followed by usually $(f=85)$, always $(f=69)$, more $(f=60)$ and most $(f=$ $55)$.

Table 5. The most frequent verbs, adjectives, and adverbs in Marathon Plus

\begin{tabular}{|c|c|c|c|c|c|}
\hline Verb & $f$ & Adjective & $f$ & Adverb & $f$ \\
\hline is & 524 & correct & 77 & there & 138 \\
\hline do & 401 & great & 54 & then & 72 \\
\hline are & 233 & social & 43 & always & 62 \\
\hline have & 206 & online & 41 & very & 59 \\
\hline like & 160 & good & 36 & too & 49 \\
\hline want & 124 & best & 33 & never & 47 \\
\hline go & 115 & true & 32 & also & 41 \\
\hline be & 103 & different & 31 & usually & 33 \\
\hline going & 94 & favorite & 30 & really & 32 \\
\hline prefer & 82 & new & 30 & rather & 31 \\
\hline was & 81 & important & 27 & now & 30 \\
\hline choose & 79 & last & 27 & together & 29 \\
\hline doing & 79 & dangerous & 25 & more & 28 \\
\hline write & 74 & interested & 25 & tomorrow & 28 \\
\hline make & 71 & sorry & 24 & most & 27 \\
\hline take & 70 & simple & 24 & tonight & 27 \\
\hline does & 69 & popular & 23 & often & 23 \\
\hline think & 69 & other & 22 & so & 22 \\
\hline say & 65 & hot & 22 & sometimes & 21 \\
\hline read & 64 & old & 21 & first & 20 \\
\hline see & 63 & responsible & 20 & later & 20 \\
\hline
\end{tabular}


A. Güdücü, \& F. Güngör / Pamukkale University Journal of Education, 54, 130-157, 2022

\begin{tabular}{|c|c|c|c|c|}
\hline use & 63 & false & 19 & here \\
\hline love & 58 & famous & 18 & sure \\
\hline match & 57 & first & 17 & today \\
\hline will & 57 & traditional & 17 & yesterday \\
\hline put & 53 & natural & 16 & when \\
\hline has & 52 & boring & 15 & again \\
\hline did & 51 & busy & 15 & well \\
\hline get & 50 & free & 15 & soon \\
\hline work & 47 & amazing & 14 & finally \\
\hline fill & 44 & big & 14 & rarely \\
\hline know & 44 & extreme & 14 & ago \\
\hline tell & 43 & historic & 14 & just \\
\hline making & 42 & interesting & 14 & ever \\
\hline come & 40 & fascinating & 13 & twice \\
\hline listen & 40 & necessary & 13 & less \\
\hline answer & 38 & tasty & 13 & definitely \\
\hline try & 36 & easy & 13 & once \\
\hline enjoy & 35 & fun & 12 & about \\
\hline help & 34 & afraid & 12 & probably \\
\hline learn & 33 & possible & 12 & next \\
\hline find & 32 & small & 12 & easily \\
\hline talking & 32 & clean & 11 & seldom \\
\hline call & 30 & late & 11 & much \\
\hline need & 30 & better & 11 & immediately \\
\hline gone & 30 & awesome & 11 & regularly \\
\hline join & 30 & entertaining & 11 & long \\
\hline using & 30 & exciting & 11 & actually \\
\hline add & 29 & same & 10 & almost \\
\hline complete & 28 & past & 10 & constantly \\
\hline
\end{tabular}

In Table 5, is $(f=524), d o(f=401)$, are $(f=233)$, have $(f=206)$ and like $(f=160)$ are the most frequent verbs. The most frequent adjectives were correct $(f=77)$, great $(f=54)$, social $(f=$ 43), online $(\mathrm{f}=41)$ and good $(f=36)$. There $(f=138)$, then $(f=72)$, always $(f=62)$, very $(f=$ 59) were the most frequent adverbs. 


\section{An Evaluation of Vocabulary Levels in accordance with CEFR}

Figure 1 shows that the percentage of A1 level vocabulary in Upswing English is 23.03, and the percentage of A2 level vocabulary is 19.34. The percentage for A1 level in Touchstone 2 was 26.84 and for A2 level was 23.45. Twenty-two-point eighty-two percent of the vocabulary in Mastermind was at A1 level and $18.75 \%$ belonged to A2 level. In More \& More, the percentage of vocabulary at A1 level was 15.65 and 13.85 at A2 level. The percentage of vocabulary at A1 level was 19.99 and 16.31 at A2 level in Marathon Plus.

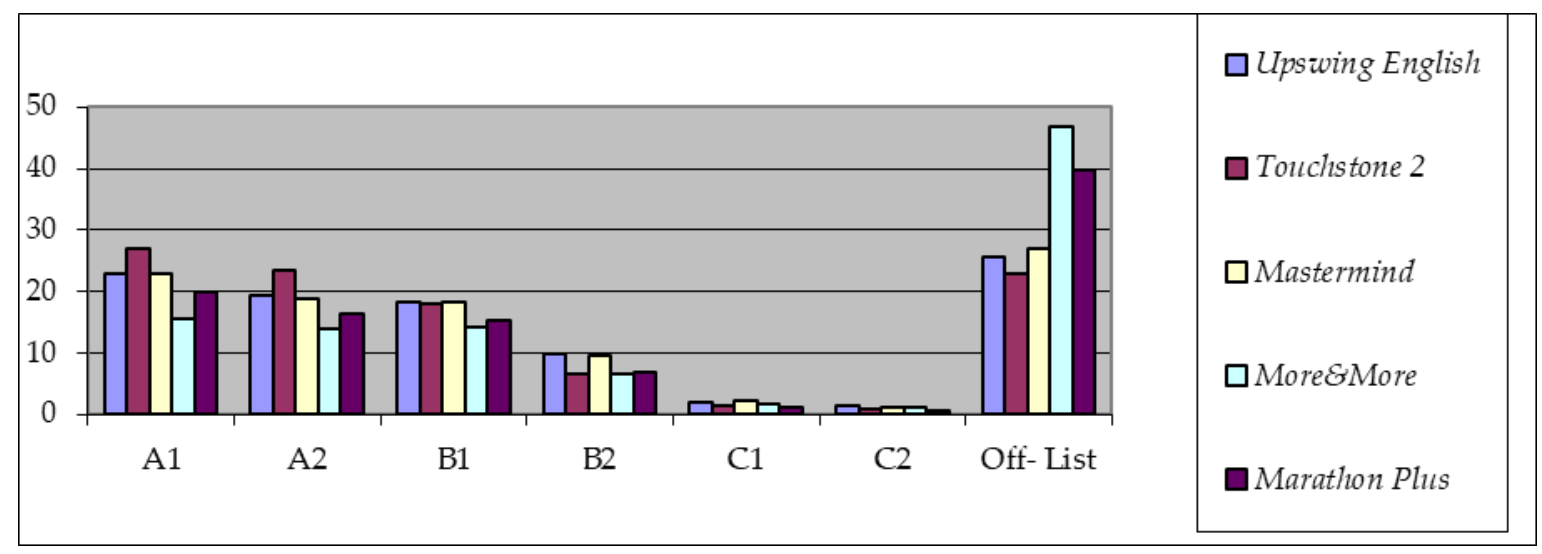

Figure 1. An evaluation of vocabulary levels in accordance with CEFR

In Upswing English, while there were words like a, all, and examples were at A1 level, ago, build, jump are some words at A2 level. In Touchstone 2, there were words like dad, minute, snow at A1 level, and words like corner, north, and opera at A2 level. The words about, kitchen, sandwich were at A1 level, add, magazines, should were at A2 level in Mastermind. In More \& More, the words such as afternoon, eyes, and family were at A1 level, and accident, call, and lucky were at A2 level. In Marathon Plus, the words like butter, now, and car were at A1 level, and actually, empty, and library were at A2 level.

\section{An Evaluation of Vocabulary Levels in accordance with BNC and COCA}

We compared the results of our analyses with BNC and COCA and presented these results in Table 6. Considering that the previous studies (e.g. Jahan et al., 2019, p. 14; Karadağ, 2019, p. 767; Thornbury, 2002, p. 21) indicate the significance of the most frequent 2000 words as a threshold for daily communication, we compared the most frequent 2000 words with the most frequent 2000 words in BNC and COCA. 
Table 6. An evaluation of vocabulary levels in accordance with BNC and COCA

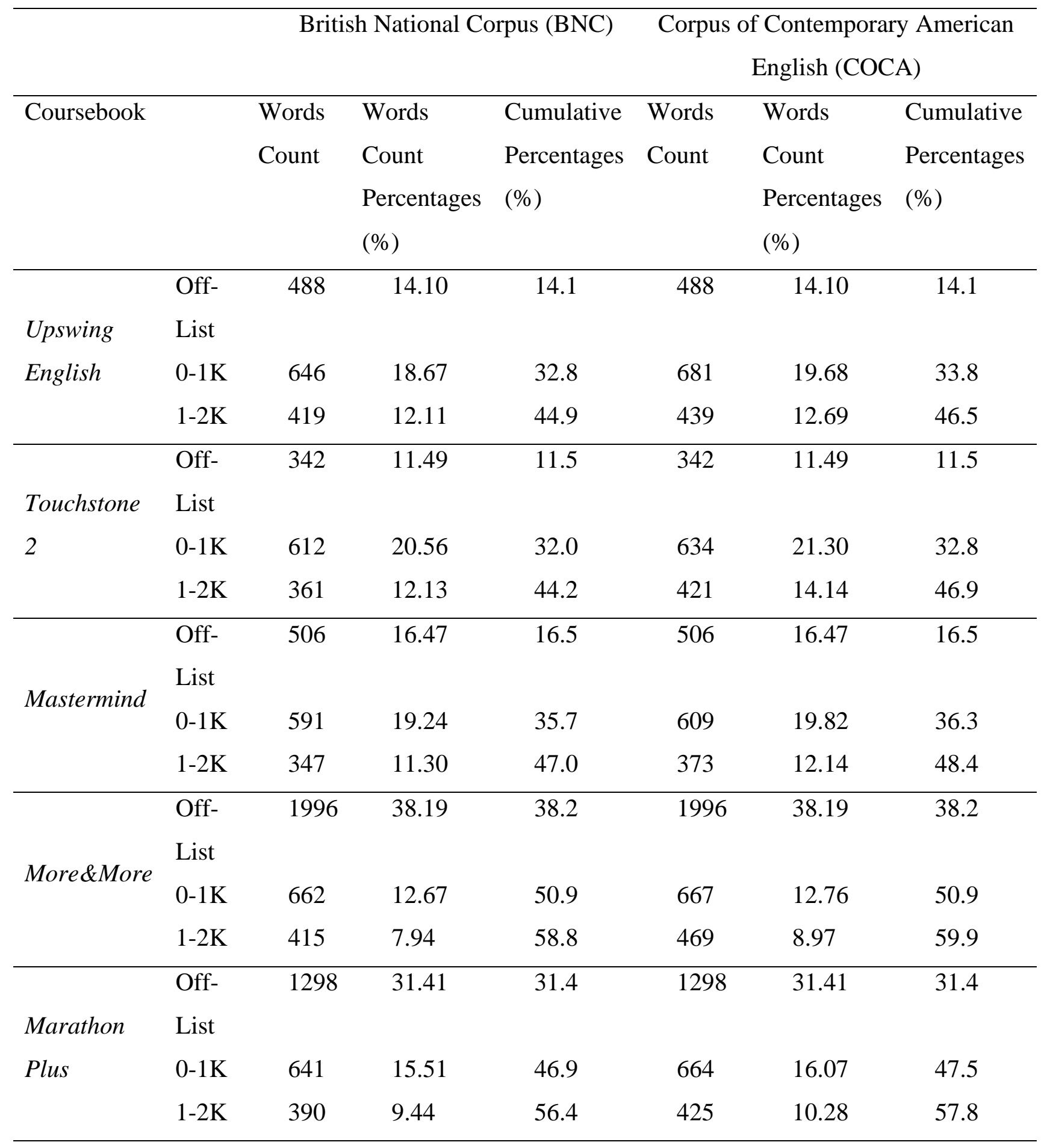

Table 6 shows that Upswing English covered $18.67 \%$ and $19.68 \%$ of the most frequent 1000 words in BNC and COCA, respectively. These percentages were 20.56 for BNC and 21.30 for COCA in Touchstone 2. While Mastermind covered $19.24 \%$ and $19.82 \%$ of the most frequent 1000 words in BNC and COCA, respectively, these percentages were 12.67 for BNC and12.76 for COCA in More \& More. The last book, Marathon Plus, covered 15.5\% and $16.07 \%$ of the most frequent 1000 words in BNC and COCA, respectively. When it 
comes to the most frequent second 1000 words, Upswing English covered $12.11 \%$ and $12.69 \%$ in BNC and COCA, respectively. These percentages were 12.13 for BNC and 14.14 for COCA in Touchstone 2. While Mastermind covered $11.30 \%$ and $12.14 \%$ of the most frequent second 1000 words in $\mathrm{BNC}$ and COCA, respectively, these percentages were 7.94\% for BNC and $8.97 \%$ for COCA in More \& More. Lastly, Marathon Plus covered $9.44 \%$ and $10.28 \%$ of the most frequent second 1000 words in BNC and COCA, respectively.

When we analyzed BNC, in Upswing English, the words such as the, you, for, answer, understanding were in the first 2000-word list. The example words in the other books were as follows: words such as and, a, I, shows, and answer in Touchstone 2; words such as the, her, to, competition, and medical in Mastermind; words $I$, and, the, extra, and speak in More $\&$ More; words such as the, and, so, glass, and bill in Marathon Plus.

When it comes to COCA, the following words were in the most frequent 2000 word list: words such as I, good, through, source, and edge in Upswing English; words your, some, player, fell, and trip in Touchstone 2; the words person, game, travel, manner, and smart in Mastermind; words the, are, said, sister, and access in More \& More; words I, way, yeah, access, and gas in Marathon Plus.

\section{An Evaluation of Vocabulary Levels in accordance with AWL}

The findings in accordance with AWL can be analyzed in Table 7.

Table 7. An evaluation of vocabulary levels in accordance with AWL

\begin{tabular}{lll}
\hline $\begin{array}{l}\text { Coursebook } \\
\text { List }\end{array}$ & $\begin{array}{l}\text { Words } \\
\text { Percentage (\%) }\end{array}$ \\
\hline $\begin{array}{l}\text { Upswing English } \\
\text { Touchstone 2 }\end{array}$ & AWL Total & $238(6.88)$ \\
Mastermind & AWL Total & $156(5.24)$ \\
More\&More & AWL Total & $197(6.41)$ \\
Marathon Plus & AWL Total & $246(4.71)$ \\
\hline
\end{tabular}


In Table 7, the percentage of AWL vocabulary in Upswing English was 6.88. The percentages of AWL vocabulary were 5.24 in Touchstone 2, 6.41 in Mastermind, 4.71 in More \& More, and 4.74 in Marathon Plus. Although More \& More had the highest number of words from AWL list, the percentage was relatively low due to the total word numbers of each book.

\section{Discussion}

Although English classes start from the second grade in Turkish public schools (MoNE, 2013, p. II), the desired level in language teaching and learning could not be achieved (Aktaş, 2004, p. 45; Coşkun-Demirpolat, 2015, p. 10). One reason for this failure might be selecting rare vocabulary items, and non-authentic reading and listening texts in foreign language teaching and learning coursebooks (Coşkun-Demirpolat, 2015, p. 15). Therefore, it is necessary to prepare coursebooks based on the corpus data of native speakers. Thus, the frequency information of the words can be accessed, and we can ensure to emphasize frequently used words in language learning and teaching. Therefore, this study compared the vocabulary frequencies in our book corpus with the reference corpora and word list. Firstly, we extracted the most frequent 50 verbs, adjectives, and adverbs. When the results were analyzed, it was remarkable that the high frequent verbs were $d o$, is, are and have. In Upswing English, the frequencies of $d o$, is, are, have were 296, 246, 164, and 140 respectively. In Touchstone 2, the frequencies of $d o$, is, are, have were 525, 280, 358, and 230 respectively. The results for other books were also very similar. These high frequencies were related to their use as verbs as well as auxiliary verbs. Apart from these verbs, the coursebooks' high frequent verbs are like, write, use, read, go, make, listen, was, going, get, prefer, share, match, be, think and want. The most frequent words were the ones indicating student activities such as read, write and complete (Catalan and Francisco, 2008). Accordingly, the use of words such as write, read and listen functions for giving instructions to the students in the coursebooks exercises in this study. When the most frequent ten adjectives in the frequency lists were considered, Upswing English and Mastermind used in Turkish public schools had adjectives such as short, correct, and natural in common. Although we expected similar numbers of adjectives from the most frequent ten in both coursebooks distributed by MoNE, the vocabulary coverage of Upswing English and Mastermind were not similar. When we analyzed the most frequent ten adjectives in a corpus-based book Touchstone 2, only four adjectives (great, good, different and new) seem to be shared by other four coursebooks. However, the frequency of these adjectives in 
Touchstone 2 was relatively higher than in the other coursebooks. More \& More and Marathon Plus were compatible with Upswing English and Mastermind. Thus, it is possible to point out that adjectives and the frequencies were similar to Upswing English and Mastermind. This study revealed that adjectives such as correct, great, new, good, social, first, favorite and different were among the most frequent ten adjectives in Upswing English, in Mastermind, More \& More, and Marathon Plus.

As Nordlund and Norberg (2020) state, language learners should frequently encounter new words to acquire the necessary vocabulary for language acquisition. However, not every word is used as often in daily life. Therefore, to learn frequent words in corpora and in word lists, the repetition of the words is of great importance (Nation, 2001). According to Thornbury (2002), if a word is encountered at least seven times within certain time intervals, its retention possibility increases. A word can be learned if it repeats eight or more times (Horst, Cobb, \& Meara, 1998). For instance, a student who encounters the verb write 103 times in Upswing English encounters the same verb 58 times in More \& More. Likewise, a student encountering the adjective good 124 times in Touchstone 2 encounters 11 times in Mastermind. Considering that the same words are repeated differently, we can conclude that the words in a coursebook with more repetitions will be easier because of the increasing numbers of repetitions.

We also evaluated the words in the coursebooks in accordance with CEFR. According to MoNE (2018a) Upswing English and Mastermind correspond to A2 level. Published as rivals, More \& More and Marathon Plus are considered A2 level. As a coursebook claiming to be at A2 level in CEFR (2013), Touchstone 2 had the highest inclusion percentage at A2 level with $23.45 \%$ as a result of the analyses. Total percentages show that, Touchstone 2 covered the vocabulary at Basic User Level (A1 and A2) with the highest percentage $(50.3 \%)$ among the analyzed books. This percentage was 42.4 for Upswing English, 41.6 for Mastermind, 29.5 for More \& More and 36.3 for Marathon Plus. As a result of their study, Alexiou, Mattheoudakis, Saratsli and Vagenas (2019) stated that A1 level coursebooks contain the words at this level. Therefore, A2 level coursebooks are expected to consist of A1 and A2 level vocabulary items. Arslan and Erarslan (2019) found that $28(10.37 \%)$ of 270 words in the vocabulary activities in Mastermind were at A1 level, $49(18.14 \%)$ of them were at A2 level, and the percentage of Basic User Level vocabulary was low with $28.51 \%$. Considering the $61.85 \%$ coverage for A1 level vocabulary in the first book and $60.21 \%$ coverage in the second book in the study of Alexiou et al. (2019), we 
expect the percentage above $50 \%$ for Basic User Level in this study. Regarding the total percentages, the coursebooks except from More \& More and Marathon Plus were close to $50 \%$. Therefore, the coursebooks were close to A2 level, but the percentages at Basic User Level of the coursebooks were relatively low in this study. Due to the relatively low basic user level percentages of the coursebooks in this study, as in some other studies (Arslan \& Erarslan, 2019), vocabulary selection criteria should be reviewed and revised except Touchstone 2, which had a higher percentage than $50 \%$.

The vocabulary size at A2 level was between 1500 and 2000 words (Milton \& Alexiou, 2009; Van Ek \& Trim, 1990). Thus, the coursebooks in this study were expected to consist of the most frequent 2000 words in BNC and COCA. These percentages were relatively low as given in the results part. The percentages of off-list words for both BNC and COCA were 14.10 in Upswing English, 11.49 in Touchstone 2, 16.47 in Mastermind, 39.19 in More \& More, and 31.41 in Marathon Plus. In Baydal's study (2016, p. 104), the coursebook Upturn in English 8 was considered not to be suitable for A2 level because of the percentages of off-list words (12.9\%) and the percentages of words in the most frequent second 1000 (9.10\%) word lists. The most frequent second 1000 words contained content words that are necessary for communication. As in other studies (e.g., Baydal, 2016; Arslan \& Erarslan, 2019), the coursebooks in this study were not appropriate to A2 level since the percentage of the most frequent second 1000 words was lower than the percentage of the most frequent first 1000, and the percentage of off-list words was also high.

Touchstone 2 seemed to be more appropriate to A2 level, as it claimed because it had higher percentage $(50.3 \%)$ at A2 level than the other coursebooks had. In addition, it contained more words (\%23.45) at A2 level than the others did. Furthermore, while Touchstone 2 covered $20.56 \%$ and $21.30 \%$ of the most frequent first 1000 words in BNC and COCA, these percentages were 12.13 and 14.14 of the most frequent second 1000 words for BNC and COCA. Considering these percentages and required vocabulary size for A2 level, we can conclude that having more words from the most frequent first 1000 and second 1000 words and fewer off-list (11.49\%) words makes Touchstone 2 closer to A2 level.

As Nation (2001, p. 22) emphasizes, "usually the 2000-word level has been set as the most suitable limit for high frequency words". In other words, knowing the most frequent 2000 words is an important threshold for language comprehension. Touchstone 2 had the highest coverage (20.56\%) in the first 1000 and the second 1000 lists of BNC as a result of analyses. In the first 1000 words, there are words such as the, a, I, you, is, and. Most frequent 
vocabulary items function as prepositions, pronouns, determiners, conjunctions, auxiliary verbs, and particles (Alexiou et al., 2019; Baydal, 2016; Biber, Johansson, Leech, Conrad \& Finegan, 1999). After excluding off-list words, we found that Touchstone 2 had the highest percentage of words (32.69\%) in the first 2000 in BNC. It was followed by Upswing English (30.78\%), Mastermind (30.54\%), Marathon Plus (24.95\%), and More \& More (20.61\%). The previous studies included very high coverage of the first 2000 words (e.g., $88.92 \%$ in Hajiyeva, 2015; 43.3\% in Shin \& Chon, 2011) in BNC, but this percentage was lower than $33 \%$ in all coursebooks.

After excluding off-list words in COCA, Touchstone 2 had the most vocabulary items in the most frequent 2000 with $35.44 \%$. This supports the argument that Touchstone writers, as McCarthy (2004) states, use corpus to determine the words used in daily life. Touchstone 2 was followed by Upswing English (32.37\%), Mastermind (31.96\%), Marathon Plus (26.35\%), More \& More (21.73\%). The coursebooks in this study could not reach $43 \%$ rate, contrary to Öztürk and Çetin's study (2018). Although the percentage found by Öztürk and Çetin (2018) was higher than this study, they argued that the coursebooks and the curriculum were not well enough to target vocabulary in frequency lists. This study has similarities to Öztürk and Çetin's study (2018), and we can suggest that the coursebooks in this study should be prepared or revised based on frequency.

Based on the AWL, Upswing English had the highest percentage (6.88\%), and More \& More had the lowest percentage (4.71\%). In Hajiyeva's study (2015, p. 136), although the words in the first 2000 -word families were $88.92 \%$ in the coursebooks, this rate in AWL was 6.5\%. Cao (2018) compared the book used by English academic students in higher education with AWL, and the rate of AWL words found in Life A2-B1 is 11.01\%. Although Cao (2018) included B1 level, the rate was low. Therefore, Cao (2018) emphasized that this rate was not enough for the students to be successful in their academic studies, and to be successful, they should be exposed to the academic words more. As stated in the eighthgrade curriculum, A2 basic level users "can understand simple expressions and expressions used frequently in areas that are essential for communication (for instance simple and personal information, family information, shopping, neighborhood and job)" (MoNE, 2018a, p. 82). The coursebooks in this study teach general English, and they should primarily include daily-life expressions and examples. Contrary to Cao's study (2018), coursebooks are not expected to include many words in AWL. Nevertheless, to include academic words 
in vocabulary learning even if they are in a limited number would be an excellent preparation for high school education (Ünlü, 2012).

\section{Conclusion}

The knowledge of sufficient vocabulary in second language results in better comprehension (Nation, 1993). Likewise, vocabulary knowledge "is only one component of language skills such as reading and speaking" (Nation \& Waring, 1997, p. 6), and learning the most frequent 2000 words improves listening comprehension and reading skills (Jahan et al., 2019). On the contrary, the lack of sufficient vocabulary knowledge limits students' success (Masrai \& Milton, 2017). These results suggest that the students using Touchstone 2, which is based on a corpus and has many words in the most frequent 2000, have a high probability of learning more vocabulary items. Considering the frequency and range factors in our analyses (Nunan, 1991), we can help learners learn the word in the coursebooks easier. Therefore, word frequency lists can be used in curriculum and coursebook design by considering the fact that students get the content of the curriculum through coursebooks (Cunningsworth, 1995). Accordingly, corpus studies play a significant role in the curriculum development, coursebook design, and dictionary production (Aijmer, 2009).

O'Keeffe et al. (2007, p. 32) found that $80 \%$ of her 10-million-word corpus consisted of the most frequent 2000 words. Therefore, the inclusion of the first 2000 words based on a corpus will cover most of the A2 vocabulary, and many previous studies confirmed this argument (Nation \& Waring, 1997, p. 239; Nordlund \& Norberg, 2020; Thornbury, 2002, p. 21). Furthermore, including academic words in a limited number from AWL would be good preparation for high school education (Ünlü, 2012) although the coursebooks in this study were used to teach general English.

The results of this study might be considered an important resource for those who design foreign language curriculum, material designers, coursebook authors, teachers, and students. In this regard, while preparing a foreign language education curriculum, curriculum developers are supposed to consider vocabulary frequency and authentic language examples of a corpus, and the curriculum can be designed accordingly. The corpus-based materials might help less proficient writers to learn appropriate vocabulary items for their levels and aspirations (Güngör, \& Uysal, 2020). Using the data in this study and similar studies, MoNE can publish recommendations and descriptors to specify basic wordlists and vocabulary items that publishers of state coursebooks should include. Authors can consider vocabulary frequency and benefit from the corpus data in activities and texts in 
the coursebooks. Data-driven activities can be used in the classroom by considering corpus data and word lists in this study. As stated in the 2023 Education Vision document, we can integrate mobile technologies containing corpus and frequency information into classrooms. Material designers can prepare activities by extracting real-life language samples in corpus (Krieger, 2003). Following this study, in-depth studies based on different corpora for different coursebooks at different grades can be conducted to further the current study.

Ethical Permission Status: In the current study, we adhered to all the ethical practice codes laid out in "The Higher Education Institutions Scientific Research and Publication Ethics Directive". We performed none of the acts defined in the second part of the directive "Acts against Scientific Research and Publication Ethics" in the current study. Since this study is a corpus analysis, ethics committee approval is not required.

Conflicts of Interest: There are no conflicts of interest.

Author Contributions: The first author, Abdurrahman Güdücü, contributed to the study in the process of literature review, collecting data, analysis of the data, and writing the article. The second author, Fatih Güngör, contributed to the study in creating the idea of the study, determining the research method, writing and reviewing the article before submission, and revising it in the review process. 


\section{References}

Aijmer, K. (2009). Introduction: Corpora and language teaching. In K. Aijmer (Ed.), Corpora and language teaching (pp. 1-10). Amsterdam: John Benjamins.

Aktaş, T. (2004). Yabancı dil öğretiminde iletişimsel yeti. Selçuk Üniversitesi Sosyal Bilimler Enstitüsü Dergisi, 12, 45-57.

Alcaraz, G. (2009). Frequency and functionality: Two keys for L2 coursebooks. International Journal of English Studies, 9(3), 61-72.

Alexiou, T., Mattheoudakis, M. Saratsli, D., \& Vagenas, A. (2019). Words don't come easy: Linguistic analysis of vocabulary in Magic Books. Journal of Applied Linguistics, 32, 25-41. https://doi.org/10.26262/jal.v0i32.7515

Alexiou, T., \& Konstantakis, N. (2009). Lexis for young learners: Are we heading for frequency or just common sense?. Selected Papers on Theoretical and Applied Linguistics, 18, 59-66.

Alhudithi, E. (2017). Corpus-based analysis of English vocabulary input provided in K-12 textbooks used in Saudi Arabia (Doctoral dissertation). Colorado State University.

Anthony, L. (2019). AntConc (3.5.8. Versiyon) [Bilgisayar Yazılımı]. Tokyo, Japonya: Waseda Üniversitesi.

Arslan, A., \& Erarslan, A. (2019). Lexical analysis of a textbook based on the EVP. International Journal of Languages' Education and Teaching, 7(1), 1-12. https://doi.org/10.18298/ijlet.3230

Baydal, D. (2016). A corpus based study on vocabulary of an A2 level English textbook (Yayınlanmamış Yüksek Lisans Tezi). Ondokuz Mayıs Üniversitesi Eğitim Bilimleri Enstitüsü, Samsun.

Biber, D., Johansson, S., Leech, G., Conrad, S. \& Finegan, E. (1999). Longman Grammar of Spoken and Written English. England: Pearson.

Cao, T. H. P. (2018). Vocabulary in EFL textbook: An analysis of "Life A2-B1" coursebook used for Vietnamese tertiary students. Proceedings of the 7th Vietnamese Young Researchers Conference in Education at Hanoi National University of Education, section 3, 548-556. 
Catalan, R. J., \& Francisco, R. M. (2008). Vocabulary input in EFL textbooks. Revista Española De Lingüística Aplicada, 21, 147-165.

Coşkun-Demirpolat, B. (2015). Türkiye'nin yabancı dil öğretimiyle imtihanı sorunlar ve çözüm önerileri. Analiz, 131, 7-19.

Cunningsworth, A. (1995). Choosing your coursebook. Oxford: Heinmann.

Çinar, K. (2015). A Corpus-based approach to Turkish EFL textbook evaluation: Single word and four-word lexical bundle frequency. (Unpublished master dissertation). Yeditepe University Graduate School of Educational Sciences: İstanbul.

Gilquin, G., \& Granger, S. (2010). How can data-driven learning be used in language teaching? In A. O'Keeffe \& M. McCarthy (Eds.), The Routledge handbook of corpus linguistics (pp. 359-370). Abingdon: Routledge.

Guan, X. (2013). A study on the application of data-driven learning in vocabulary teaching and learning in China's EFL class. Journal of Language Teaching and Research, 4(1), 105-112. https://doi.org/10.4304/jltr.4.1.105-112

Güngör, F. (2016). Crosslinguistic analysis of lexical bundles in L1 English, L2 English, and L1 Turkish research articles (Unpublished doctorate dissertation). Gazi Üniversitesi Eğitim Bilimleri Enstitüsü: Ankara.

Güngör, F., \& Uysal, H. H. (2020). Lexical bundle use and crosslinguistic influence in academic texts. Lingua, 242, 102859.

Hajiyeva, K. (2015). A corpus-based lexical analysis of subject-specific university textbooks for English majors. Ampersand, 2, 136-144.

Horst, M., Cobb, T., \& Meara, P. (1998). Beyond a clockwork orange: Acquiring second language vocabulary through reading. Reading in a Foreign Language, 11, 207-223.

Hunston, S. (2002). Corpora in applied linguistics. Cambridge: Cambridge University Press

Jahan, K, Mahmood, M.A., \& Azhar, W. (2019). Lexical analysis of intermediate English coursebooks: A corpus based study. International Journal of Educational Sciences, 24(1-3), 13-22.

Johansson, S. (2009). Some thoughts on corpora and second-language acquisition. In K. Aijmer (Ed.), Corpora and language teaching (pp. 33-44). Amsterdam: John Benjamins. 
Jordan, G., \& Gray, H. (2019). We need to talk about coursebooks. ELT Journal, 73(4), 438446.

Karadağ, Ö. (2019). Neden bir çocuk dili derlemine ihtiyacımız var? Ana Dili Ĕ̈itimi Dergisi, 7(3), 765-780.

Kayaoğlu, M. N. (2011). A critical apprasial of the language textbook. KEFAD, 12(4), 341356.

Kim, S. S. (2002). A corpus-based analysis of the words in the elementary school English textbooks. English Teaching, 57(3), 253-277.

Kirana, D. P., Basthomi, Y., Isnawati, U. M., \& Fitriani, A. (2018). A corpus-based study of vocabulary as input in EFL text-book: A case in an Indonesian Islamic College. Journal of Applied Linguistics and Language Research, 5(5), 93-104.

Kitao, K. \& Tanaka, S. (2009). Characteristics of Japanese junior high school English textbooks: From the viewpoint of vocabulary and readability. Journal of Culture and Information Science, 4(1), 1-10.

Krieger, D. (2003). Corpus linguistics: What it is and how it can be applied to teaching. The Internet TESL Journal, 9(3).

Leech, G. (2011). Frequency, corpora and language learning. In F. Meunier, S. De Cock, G. Gilquin \& M. Paquot (Eds.), A taste for corpora-in honour of Sylviane Granger (pp. 7-32). Amsterdam: John Benjamins

Masrai, A. \& Milton, J. (2017). Recognition vocabulary knowledge and intelligence as predictors of academic achievement in EFL context. TESOL International Journal, $12(1), 128-142$.

McCarthy, M. (2004). Touchstone from Corpus to Coursebook. Cambridge: Cambridge University Press.

McEnery, T. \& Hardie, A. (2012). Corpus linguistics method, theory, and practice. Cambridge: Cambridge University Press.

McEnery, T. \& Xiao, R. (2010). What corpora can offer in language teaching and learning. In E. Hinkel (Ed.), Handbook of research in second language teaching and learning (pp: 364-380). London\& New York: Routledge. 
McEnery, T., \& Wilson, A. (1997). Teaching and language corpora (TALC). ReCALL, 9(1), $5-14$.

Milton J., Alexiou T. (2009) Vocabulary size and the Common European Framework Of Reference for languages. In B. Richards, M. H. Daller, D. D. Malvern, P. Meara, J. Milton, \& J. Treffers-Daller (Eds.), Vocabulary studies in first and second language acquisition (pp. 194-211). Palgrave Macmillan, London.

Mindt, D. (1996). English corpus linguistics and the foreign langauge teaching syllabus. In J. Thomas \& M. Short (Eds.), Using corpora for language research (pp. 232-247). Harlow: Longman.

Ministry of National Education. (2013). Ilköğretim kurumları (ilkokullar ve ortaokullar) Ingilizce dersi (2,3,4,5,6,7 ve 8. sinfflar) ögretim programı. Ankara: Milli Eğitim Bakanlığg1.

Ministry of National Education. (2018a). İlköğretim Kurumları (Illkokullar ve Ortaokullar) Ingilizce Dersi (2,3,4,5,6,7 ve 8. Sinıflar) Öğretim Programı. Ankara: Milli Eğitim Bakanlığg1.

Ministry of National Education. (2018b). Turkey's education vision 2023. Milli Eğitim Bakanlığı.

Nation, I.S.P. (1993) Vocabulary size, growth and use. In R. Schreuder and B. Weltens (Eds.), The bilingual lexicon (pp. 115-134). Amsterdam/Philadelphia: John Benjamins.

Nation, I.S.P. (2001). Learning vocabulary in another language. Cambridge: Cambridge University Press.

Nation, P., \& Waring, R. (1997). Vocabulary size, text coverage and wordlists. In N. Schmitt \& M. McCarthy (Eds.), Vocabulary: description, acqusition and pedagogy 1 (pp. 6-19). Cambridge: Cambridge University Press.

Nordlund, M. (2016). EFL textbooks for young learners: A comparative analysis of vocabulary. Education Inquiry, 7(1), 27764.

Nordlund, M., \& Norberg, C. (2020). Vocabulary in EFL teaching materials for young learners. International Journal of Language Studies, 14(1), 89-116.

Nunan, D. (1991). Language teaching methodology (Vol. 192). New York: Prentice Hall. 
O'Keeffe, A., McCarthy, M., \& Carter, R. (2007). From corpus to classroom: Language use and language teaching. Cambridge University Press.

Öztürk, M., \& Çetin, K. B. (2018). Lexical component of young learners' English syllabus in Turkey. International Journal of Languages Education, 6(3), 308-316.

Sheldon, L. E. (1988). Evaluating ELT textbooks and materials. ELT Journal, 42(4), 237246.

Shin, D., \& Chon, Y.V. (2011). A Corpus-based Analysis of Curriculum-based Elementary and Secondary English Textbooks. Multimedia Assisted Language Learning, 14(1), 149-175.

Sinclair, J., \& Renouf, A. (1988). A lexical syllabus for language learning. Vocabulary and Language Teaching, 140, 60.

Sun, Y., \& Dang, T. N. Y. (2020). Vocabulary in high-school EFL textbooks: Texts and learner knowledge. System, 93, 102279.

Suna, Y., \& Durmuşçelebi, M. (2013). Türkiye'de yabancı dil öğrenme- öğretme problemine ilişkin yapılan çalışmaların derlemesi. OPUS Türkiye Sosyal Politika ve Çalışma Hayatı Araştırmaları Dergisi, 3(5), 7-24.

Thornbury, S. (2002). How to teach vocabulary. Essex: Pearson Education Limited.

Touchstone CEFR Guide Level 2 (2013). Cambridge University Press: Cambridge.

Turanlı, A. (2004). Yabanc1 dil öğretiminde istenmeyen öğrenci davranışları ve önleyici yönetim yaklaşımları. Eurasian Journal of Educational Research, 17, 31-44.

Ünlü, F. (2012). Loading, distribution, and repetition patterns of the 2000 high frequency words of general English in an EFL coursebook (Yayınlanmamış Yüksek Lisans Tezi). Karadeniz Teknik Üniversitesi Sosyal Bilimler Enstitüsü, Trabzon.

Van Ek, J. A., \& Trim, J. L. M. (1991). Threshold level 1990. Council of Europe.

Wahid, R. (2011). The use of corpus-based techniques in literary analysis: Exploring learners' perceptions. Asiatic, 5 (1), 104-128.

WebLingua (n.d.). Textinspector. https://textinspector.com/workflow

Zimmerman, C. B., \& Schmitt, N. (2005). Lexical questions to guide the teaching and learning of words. The CATESOL Journal, 17(1), 164-170. 


\title{
Sekizinci Sınıf Seviyesinde Kullanılan İngilizce Ders Kitaplarındaki Kelime Öğelerinin Karşılaştırılması*
}

\author{
Abdurrahman Güdücü** Fatih Güngör***
}

- Geliş Tarihi: 21.09.2020 • Kabul Tarihi: 23.06.2021 • Çevrimiçi Yayın Tarihi: 02.11.2021

\section{$\ddot{O} \mathbf{z}$}

$\mathrm{Bu}$ araştırmada Türkiye'de sekizinci sınıf seviyesinde kullanılan ders kitaplarındaki kelime öğelerinin analiz edilmesi ve kelime sıklıklarının Avrupa Ortak Dil Çerçeve Metni (CEFR), İngiliz Ulusal Derlemi (BNC), Çağdaş Amerikan İngilizcesi Derlemi (COCA) ve Akademik Kelime Listesi (AWL) ile karşılaştırılması amaçlanmıştır. Buna ek olarak, en sık kullanılan 50 fiil, sıfat ve zarf belirlenmiştir. Araştırma sonucunda, sık kullanılan fiiller do, is, are, have, sık kullanılan sıfatlar correct, short, natural, great, good, new, social, first, favorite ve s1k kullanilan zarflar ise then, really, there, here, very, always, too, well, more, usually ve often olarak belirlenmiştir. Araştırma sonucunda Touchstone 2 kitabında yer alan kelimeler Avrupa Ortak Dil Çerçeve Metni A2 seviyesi, İngiliz Ulusal Derlemi ve Çağdaş Amerikan İngilizcesi Derleminin ilk 2000 kelime listeleri ile çoğunlukla uyuşmaktayken incelenen diğer kitaplarda tatmin edici bir oran elde edilememiştir. Akademik Kelime Listesi dikkate alındığında Upswing English kitabında yer alan kelimeler en yüksek uyum oranına sahiptir.

Araştırma sonucunda, Touchstone 2 kitabı diğer kitaplardan daha yüksek oranlara sahip olsa bile kitap yazarlarının kelime seçimlerini araştırmanın sonuçlarını dikkate alarak revize etmeleri gerektiği sonucuna ulaşılmıştır.

Anahtar sözcükler: kelime ögeleri, kelime sıklığı, ders kitapları, derlem-temelli çalışma.

\section{Atıf:}

Güdücü, A. ve Güngör, F. (2022). Sekizinci sınıf seviyesinde kullanılan İngilizce ders kitaplarındaki kelime öğelerinin karşıllaştırılması. Pamukkale Üniversitesi Eğitim Fakültesi Dergisi, 54, 130-157.doi:10.9779/pauefd. 798049.

\footnotetext{
* Bu çalışma ikinci yazarın danışmanlığında ilk yazarın "Sekizinci Sınıf Seviyesinde Kullanılan İngilizce Ders Kitaplarındaki Kelime Öğelerinin Karşılaştırılması" isimli yüksek lisans tezinden üretilmiștir.

** Öğretmen, Milli Eğitim Bakanlığı, ORCID ID: 0000-0003-4072-5009, abdrrhmngdc@gmail.com

*** Dr. Öğr. Üyesi, Afyon Kocatepe Üniversitesi, ORCID ID: 0000-0002-0800-4212, fgungor@aku.edu.tr
} 


\section{Giriș}

Yabancı dil olarak İngilizce öğretiminde kullanılan ders kitapları kelime öğelerinin öğrenilebilmesi için temel kaynaktır (Jordan ve Gray, 2019). Özellikle, Türkiye gibi anadili İngilizce olmayan ve günlük hayatta hedef dilin kullanılma şansının az olduğu ülkelerde ders kitapları etkili bir dil öğretiminin temel kaynağını oluşturmaktadır (Kayaoğlu, 2011). Ülkemizde gerçekleştirilen dil öğretiminde öğrencilerin dile maruz kalma süreleri okul ve sınıf ile sınırlı kalmaktadır (Suna ve Durmuşçelebi, 2013). Bu nedenle, ders kitaplarıyla sunulan içerikler dil öğreniminde önemlidir. Dolayısıyla, dil öğretiminde yaygın olarak kullanımı nedeniyle ders kitapları dil öğretiminde önemli bir yere sahiptir (Turanlı, 2004) ve öğrenciler için en önemli kelimelerin seçilmesi gereklidir (Sun ve Dang, 2020).

Alan yazındaki önceki çalışmalara bakıldığında, çalışmaların birçoğu ilkokul ders kitaplar1 (Alcaraz, 2009; Alexiou ve Konstantakis, 2009; Kim, 2002; Nordlund ve Norberg, 2020), ortaokul ders kitapları (Catalan ve Francisco, 2008; Kitao ve Tanaka, 2009), ve üniversite ders kitapları (Hajiyeva, 2015) üzerinde yoğunlaşmıştır. Ülkemizde sekizinci sınıf seviyesinde bir kitabın (Ünlü, 2012), Touchstone 1 kitabıyla 11 ders kitabının (Çinar, 2015) ve A2 seviyesindeki bir ders kitabının Avrupa Ortak Dil Çerçeve Metni (Baydal, 2016) ile karşılaştırıldığı çalışmalara rastlanmaktadır. Bu araştırma önceki çalışmalardan sınıf seviyesi (sekizinci sınıf), seçilen ders kitaplarının seviyesi (A2), kullanılan derlem ve kelime listeleri bakımından önceki çalışmalardan farklıdır. Önceki çalışmalara kıyasla, İngilizce ders kitaplarını derlem temelli inceleyip karşılaştıran çalışmaların nispeten daha az olması sebebiyle, yapılan bu çalışma alan yazına katkı sağlaması ve ortaya çıkan sonuçların dikkate alınarak sunulan önerilerin öğretim programı ve materyal tasarımcılarına, öğretmen ve öğrencilere katkı sağlaması bakımından önem teşkil etmektedir.

\section{Alan Yazın}

\section{Dil Eğitimi ve Ders Kitapları}

Dil öğretiminde sıklıkla kullanılan kaynaklardan olan ders kitapları, öğretim programlarının hedeflerini göstermede rol oynadığından (Sheldon, 1988), dil öğrenenler kelime öğelerinin büyük bir çoğunluğunu ders kitaplarından edinmektedir (Cao, 2018; Cunningsworth, 1995; Nordlund, 2016; Kirana, Basthami, Isnawati ve Fitriani, 2018). Bu durum ders kitaplarındaki kelimelerin seçilirken kişilerin ihtiyaçlarını karşılaması gerektiği gerçeğini ortaya çıkarmaktadır. Ancak, Türkiye'deki ders kitaplarında kelime seçimi için belirgin bir kriter olmamakla beraber sadece ünite sonlarında öğrenilmesi gereken kelimelerin 
bulunduğu listeler yer almaktadır (Baydal, 2016). Bu nedenle, ders kitabı yazarları kelime seçimi yaparken bazı kriterleri göz önünde bulundurmak zorundadırlar. Bir dilde birçok kelime yer almasına rağmen, bu kelimelerin hepsi aynı düzeyde kullanışlı değildir (Nation ve Waring, 1997). Bu durumda, "Hangi kelime yabancı dil öğrencisine öğretilmeli?, Ders kitapları hangi kelimeleri içermeli?, Öğrenciler ne kadar kelime bilgisine sahip olmalı?” gibi sorular akla gelmektedir. Ortalama bir yabancı dil öğrencisinin anadil konuşurunun sahip olduğu kelime bilgisi büyüklüğüne sahip olması beklenemez (Alcaraz, 2009). Bu yüzden, kelime bilgisi büyüklüğü ve kelime sıklıkları üzerinde durulmalıdır (Nunan, 1991).

Kelime bilgisi dil öğrenimin önemli parçası olarak görülmekte (Guan, 2013) ve direkt olarak dil öğrenenlerin okuma ve yazma becerisini etkilemektedir (Nation ve Waring, 1997). Kelime sıklığı bilgisi kelime seçiminde kullanılan ilk kriterdir çünkü sıklık bilgisi ile dil öğrenenler en sık kullanılan kelimelere aşina olurlar ve bu sayede anlamada güçlük çekmezler (Alhudithi, 2017). Bir başka ifadeyle, sık olarak kullanılan kelimeler dil öğrenenlerin ihtiyaçlarını belirtmektedir (Leech, 2011; Zimmerman ve Schmitt, 2005). Kelime seçiminde kullanılan ikinci kriter ise kelime bilgisi büyüklüğüdür. Günlük hayatta karşılaşılabilecek birçok durum için gerekli olan kelime bilgisi büyüklüğü eşiği 2000 kelimedir (Jahan, Mahmood ve Azhar, 2019; O’Keeffe, McCarthy ve Carter, 2007; Thornbury, 2002) ve sık kullanılan ilk 2000 kelimenin öğrenilmesi öğrencilerin dinlediğini anlama ve okuma becerilerini geliştirmekte ve bu durum öğrencilerin dil öğrenimlerini iyileştirmektedir. Bu bağlamda, derlem çalışmaları sonucu ortaya çıkan en sık kullanılan ilk 1000 ya da 2000 kelimenin kullanılmasının işlevsel olduğu düşünülmektedir. Bu nedenle, A2 seviyesindeki ders kitaplarında, s1k kullanılan 2000 kelimenin üzerinde durulmas1 gerekmektedir.

\section{Dil Eğitiminde Derlem Kullanımı ve Veri Yönlendirmeli Öğrenme}

Derlemden elde edilen veriler, dünyada ders kitaplarındaki kelime seçimlerini şekillendirmeye başlamıştır. Wahid'in (2011) belirttiği gibi derlemin doğrudan olarak dil öğretiminde kullanılması olan Veri Yönlendirmeli Öğrenme (VYÖ) uygulamaları,

öğrencilere kelimelerin özgün metinler içerisindeki yerlerini belirleme ve bağlam içerisindeki durumlarını gözlemlemelerine yardımcı olmaktadır (Guan, 2013). VYÖ’yü dil metodolojisine uygulayabilmek için, Gilquin ve Granger (2010, s. 360) "bir derlem ve derlemi işler hale getirebilmek için kullanılan bir araç olan bağımlı sıralı dizin yazılımı" şeklinde iki kaynak önermiştir. Dolayısıyla, derlemlerin sınıf ortamına teknoloji yardımıyla getirilmesi ile beraber dil öğretiminde öğrencilere özgün ve geniş örnekler sunulabilecektir. 
Ülkemizde açıklanan 2023 Eğitim Vizyonu belgesinde, dil öğretiminin çevrimiçi ve mobil teknolojiler ile desteklenmesi, yabancı dil öğretiminin öğrenci için en uygun yöntemlerin seçilerek öğrenci odaklı olacağından bahsedilmiştir (MEB, 2018b). 2023 Eğitim Vizyonu belgesinde bahsedilen teknoloji kullanımı ve öğrenci merkezli öğretimin merkeze alındığı bir yaklaşım VYÖ uygulamaları içinde geçerlidir. Örneğin, öğrenciler derlem ile etkileşim haline geçerler ve dilin özelliklerini kendileri keşfederler (McEnery ve Wilson, 1997) ya da bir derlem, materyal ve öğretim programlarının tasarlanmasında, sınıf içi kelime ve dilbilgisi öğrenimi aktivitelerinde kullanılabilir (Johansson, 2009).

Öğretim programı türlerinden biri olan sözcük odaklı öğretim programı derlem temelli bir öğretim programı tasarımıdır (Hunston, 2002). Sözcük odaklı öğretim programının, en yaygın kelime formlarını, kullanım örneklerini ve sözcük birleşimlerini içermesi beklenmektedir (Sinclair ve Renouf, 1988). Bir diğer ifadeyle, derlem temelli öğretim programı "bir tür okul İngilizcesi” öğretmekten daha fazlasıdır (Mindt, 1996). Dahası, derlem öğretim, öğrenme ve değerlendirme süreçleri için bir araç olarak kullanılmaktadır (McEnery ve Xiao, 2011).

\section{Çalışmanın Amacı}

Kelime bilgisinin önemi ve kelime bilgisinin derlem ile olan ilişkisi göz önünde bulundurulduğunda, bu araştırmada İngiliz Ulusal Derlemi (BNC), Çağdaş Amerikan İngilizcesi Derlemi (COCA), Akademik Kelime Listesi (AWL) ve Avrupa Ortak Dil Çerçeve Metni (CEFR) temele alınarak Upswing English, Mastermind, More \& More, Marathon Plus ve Touchstone 2 kitaplarındaki kelimelerin sıklık bilgilerinin ve yer aldıkları kelime seviyelerinin incelenmesi amaçlanmıştır. Belirtilen ilk iki kitap 2019- 2020 eğitim öğretim yılında Türk devlet okullarında kullanılmıştır. More \& More ve Marathon Plus kitapları ise ülkemizde devlet okulları ve özel okullarda alternatif ders kitabı olarak kullanılmaktadır. Touchstone 2 kitabı ise derlem temele alınarak hazırlandığ kitaptır. Bu amaçla, seçilen ders kitaplarından oluşturulan derlemdeki kelimelerin İngilizce öğretimi ve öğreniminde öncelikli olarak kullanılması gereken hedef kelimeler içerisinde ne ölçüde yer aldığının tespiti amaçlanmıştır. Aynı zamanda, bu araştırmada VYÖ yaklaşımı ve 2023 Eğitim Vizyonu göz önünde bulundurularak araştırma sonucunda dil eğitimi alanında bazı önerilerde bulunulması amaçlanmıştır. Bu amaçla aşağıdaki sorulara cevap aranmıştır:

1. Seçilen kitaplarda en s1k yer alan ilk 50 fiil, sıfat ve zarf hangileridir? 
2. Seçilen kitaplardan elde edilen derlemlerde yer alan kelimeler English Vocabulary Profile'a (EVP) göre CEFR'de hangi seviyelerde yer almaktadır?

3. Seçilen kitaplarda en sık kullanılan kelimeler, İngiliz Ulusal Derlemi (BNC), Çağdaş Amerikan İngilizcesi Derlemi (COCA) ve Akademik Kelime Listesi'nde (AWL) yer alan kelimeleri ne ölçüde kapsamaktadır?

\section{Yöntem}

$\mathrm{Bu}$ araştırma, derlem temelli bir araştırmadır. McEnery ve Hardie'ye (2012, s. 6) göre derlem temelli çalışmalarda derlemden elde edilmiş veriler "genel anlamda alan yazında var olan bir teori ya da bir hipotezi keşfetmek, geçerliliğini sağlamak, reddetmek ya da yeniden tanımlamak için kullanılır”. Derlem temelli çalışmalar, bir teori ya da hipotez özelinde belirli yapı veya bir işlevin analiz edildiği çalışmalardır (Güngör, 2016). Bu bağlamda, seçili ders kitaplarında yer alan kelimelerin sıklık bilgilerinin referans derlemler özelinde incelenmesi bakımından bu araştırma derlem temelli bir çalışmadır.

\section{Veri Toplama Süreci ve Analizi}

Millî Eğitim Bakanlığı (MEB) tarafından 2019-2020 eğitim-öğretim y1lında okullara ücretsiz olarak dağıtılan Upswing English ve Mastermind kitaplarının yanı sıra Türk yazarlar tarafından yazılmış ve özel yayınevleri tarafından yayınlanmakta olan More\&More ve Marathon Plus kitapları bu araştırmada incelenmiştir. Bunun yanı sıra, anadili İngilizce olan yazarlar ve uluslararası yayınevi tarafından yayınlanan, derlem temelli bir kitap olan Touchstone 2 kitabı da çalışmaya dâhil edilmiştir. Bu kitaplardan elde edilen derlemler AntConc (Anthony, 2019) programı ile analiz edilmiştir. Analizler sonrası, kelime sıklı̆̆ bilgileri Excel dosyasına aktarılmış ve kelime sıklığı listeleri oluşturulmuştur. Bu listeler kullanılarak sık kullanılan ilk 50 fiil, sıfat ve zarf listeleri çevrimiçi erişim sağlayan Textinspector (WebLingua) programı yardımıyla belirlenmiş ve aynı program kullanılarak kelime sıklığı listelerinde yer alan kelimeler CEFR, BNC, COCA ve AWL'ye göre değerlendirilmiştir. Araştırmada yer alan kitaplardaki en sık kullanılan ilk 50 fiil, sıfat ve zarfı belirlemek için Textinspector (WebLingua) aracında yer alan "Tagger" fonksiyonu kullanılmıştır. Tagger'dan elde edilen fiil, sıfat ve zarf listeleri Excel dosyasına aktarılmıştır. Tagger'dan elde edilen fiil, sıfat ve zarf listelerinde sıklık bilgilerinin bulunmamas1 nedeniyle daha önceden oluşturulan sıklık listelerinde bu fiil, sıfat ve zarflar tek tek aratılmış ve sıklık bilgileri not edilmiştir. Sonraki aşamada, elde edilen bu listelerde yer alan kelimeler AntConc (Anthony, 2019) programı üzerinde yer alan bağımlı sıralı dizin satırları 
kullanılarak tek tek kontrol edilmiştir. Burada amaç, fiil, sıfat ya da zarf listesinde yer alan ve sıklık bilgisi verilen kelimelerin kitap içerisinde fiil, sıfat veya zarf olarak kaç kez kullanıldığı ve bu bilginin sıklık listesindeki bilgi ile örtüşüp örtüşmediğinin tespit edilmesidir.

\section{Bulgular}

Bu bölümde, incelenen ders kitaplarında sık kullanılan 50 fiil, sıfat ve zarf belirlenmiş ve kelimelerin sıklık bilgileri CEFR, BNC, COCA ve AWL ile karşılaştırılmıştır.

\section{Sekizinci Sınıf Ders Kitaplarında Sık Kullanılan 50 Fiil, Sıfat ve Zarf}

Araştırma sonucunda sık kullanılan 50 fiil, sıfat ve zarf listesi oluşturulmuştur. Upswing English kitabında sık kullanılan 50 fiil, sıfat ve zarf Tablo 1'de gösterilmiştir.

Tablo 1. Upswing English Kitabında Sik Yer Alan Fiil, Sifat ve Zarflar

\begin{tabular}{|c|c|c|c|c|c|}
\hline Fiil & $f$ & Sifat & $f$ & Zarf & $f$ \\
\hline do & 296 & natural & 47 & then & 88 \\
\hline is & 246 & social & 46 & there & 73 \\
\hline are & 164 & great & 35 & very & 53 \\
\hline have & 140 & short & 33 & always & 39 \\
\hline like & 113 & correct & 32 & usually & 39 \\
\hline write & 103 & good & 27 & most & 33 \\
\hline use & 101 & different & 27 & first & 32 \\
\hline read & 93 & interesting & 26 & often & 30 \\
\hline go & 75 & favorite & 25 & also & 29 \\
\hline make & 72 & possible & 24 & well & 27 \\
\hline take & 68 & first & 22 & again & 27 \\
\hline work & 63 & teen & 21 & about & 26 \\
\hline does & 61 & other & 20 & sometimes & 22 \\
\hline listen & 61 & old & 18 & too & 22 \\
\hline see & 56 & long & 17 & now & 21 \\
\hline be & 52 & popular & 17 & finally & 18 \\
\hline give & 50 & related & 15 & together & 18 \\
\hline think & 50 & necessary & 14 & so & 16 \\
\hline prefer & 49 & better & 14 & rather & 16 \\
\hline love & 47 & online & 13 & ever & 14 \\
\hline
\end{tabular}




\begin{tabular}{|c|c|c|c|c|c|}
\hline did & 42 & new & 13 & never & 14 \\
\hline help & 40 & bad & 12 & really & 14 \\
\hline get & 40 & dangerous & 12 & today & 11 \\
\hline was & 40 & high & 12 & here & 11 \\
\hline ask & 38 & main & 12 & probably & 11 \\
\hline doing & 36 & responsible & 12 & yet & 10 \\
\hline follow & 33 & daily & 11 & all & 9 \\
\hline match & 32 & important & 11 & else & 9 \\
\hline has & 32 & large & 11 & just & 9 \\
\hline talk & 31 & traditional & 11 & as & 8 \\
\hline complete & 28 & human & 10 & much & 8 \\
\hline want & 26 & false & 10 & alone & 7 \\
\hline look & 24 & historic & 10 & soon & 7 \\
\hline know & 23 & interested & 10 & later & 7 \\
\hline understand & 23 & international & 10 & sure & 6 \\
\hline buy & 22 & scientific & 10 & tomorrow & 5 \\
\hline prepare & 22 & last & 9 & even & 5 \\
\hline going & 22 & cultural & 9 & exactly & 5 \\
\hline $\mathrm{am}$ & 21 & exciting & 9 & ago & 4 \\
\hline need & 20 & refundable & 9 & almost & 4 \\
\hline tick & 19 & few & 8 & definitely & 4 \\
\hline shopping & 19 & adventurous & 8 & effectively & 4 \\
\hline come & 18 & common & 8 & regularly & 4 \\
\hline find & 18 & entertaining & 8 & approximately & 3 \\
\hline choose & 17 & famous & 8 & especially & 3 \\
\hline invented & 17 & simple & 8 & everywhere & 3 \\
\hline learn & 17 & Turkish & 8 & fairly & 3 \\
\hline put & 17 & sure & 7 & firmly & 3 \\
\hline mean & 16 & active & 7 & rarely & 3 \\
\hline search & 15 & afraid & 7 & enough & 2 \\
\hline
\end{tabular}

Tablo 1'e göre Upswing English kitabında en sık yer alan fiil do $(f=296)$ olmuştur. Is $(f=$ $246)$, are $(f=164)$, have $(f=140)$ ve like $(f=113)$ fiilleri kitap içerisinde siklıkla yer alan fiiller arasında yer almaktadır. Sik kullanılan sifatlarda, ilk sirada natural $(f=47)$ sifatı yer 
A. Güdücü ve F. Güngör/ Pamukkale Üniversitesi Eğitim Fakültesi Dergisi, 54, 130-157, 2022

almaktadir. Natural sifatını sirasiyla social $(f=46)$, great $(f=35)$, short $(f=33)$ sifatları takip etmektedir. En sik kullanılan zarf then $(f=88)$ zarfidir. There $(f=73)$, very $(f=53)$, always $(f=39)$ ve usually $(f=39)$ zarfları sık kullanılan diğer zarflardır.

Tablo 2. Touchstone 2 Kitabında Sik Yer Alan Fiil, Sifat ve Zarflar

\begin{tabular}{|c|c|c|c|c|c|}
\hline Fiil & $f$ & Sifat & $f$ & Zarf & $f$ \\
\hline do & 525 & good & 124 & then & 143 \\
\hline are & 358 & new & 95 & really & 111 \\
\hline is & 280 & free & 73 & too & 77 \\
\hline have & 230 & different & 49 & here & 74 \\
\hline was & 167 & next & 46 & just & 69 \\
\hline go & 160 & long & 44 & now & 66 \\
\hline going & 155 & own & 40 & actually & 43 \\
\hline like & 154 & bad & 38 & very & 41 \\
\hline use & 150 & great & 34 & more & 31 \\
\hline get & 149 & sure & 33 & again & 28 \\
\hline listen & 149 & other & 30 & often & 28 \\
\hline take & 106 & first & 28 & maybe & 27 \\
\hline did & 105 & favorite & 28 & always & 26 \\
\hline be & 104 & interesting & 28 & never & 25 \\
\hline think & 103 & best & 27 & also & 21 \\
\hline make & 96 & true & 27 & so & 20 \\
\hline complete & 91 & last & 26 & ever & 20 \\
\hline say & 82 & short & 26 & usually & 20 \\
\hline look & 82 & old & 25 & probably & 19 \\
\hline know & 79 & special & 25 & together & 17 \\
\hline ask & 75 & simple & 25 & away & 16 \\
\hline see & 75 & better & 24 & well & 15 \\
\hline talk & 74 & sorry & 23 & back & 15 \\
\hline find & 69 & nice & 22 & else & 15 \\
\hline want & 65 & interested & 21 & today & 14 \\
\hline write & 64 & top & 19 & almost & 14 \\
\hline were & 62 & big & 18 & sure & 12 \\
\hline practice & 61 & same & 17 & ago & 12 \\
\hline
\end{tabular}




\begin{tabular}{|c|c|c|c|c|c|}
\hline mean & 59 & regular & 17 & still & 12 \\
\hline does & 55 & few & 16 & less & 12 \\
\hline read & 51 & able & 16 & anyway & 11 \\
\hline tell & 51 & false & 16 & naturally & 11 \\
\hline has & 50 & tall & 16 & sometime & 11 \\
\hline learn & 48 & correct & 14 & sometimes & 11 \\
\hline got & 47 & easy & 14 & even & 10 \\
\hline need & 47 & expensive & 14 & tomorrow & 10 \\
\hline give & 45 & hard & 13 & pretty & 10 \\
\hline check & 44 & cold & 12 & that & 8 \\
\hline guess & 43 & funny & 12 & ahead & 8 \\
\hline answer & 41 & happy & 12 & exactly & 8 \\
\hline compare & 39 & ready & 12 & soon & 7 \\
\hline remember & 39 & late & 11 & already & 6 \\
\hline choose & 37 & hot & 11 & anywhere & 6 \\
\hline love & 35 & sick & 11 & alike & 5 \\
\hline play & 34 & young & 11 & definitely & 5 \\
\hline speaking & 33 & Chinese & 10 & especially & 5 \\
\hline talking & 32 & busy & 10 & finally & 5 \\
\hline call & 31 & curly & 10 & everywher & 4 \\
\hline doing & 31 & main & 10 & far & 4 \\
\hline watch & 30 & tired & 10 & generally & 4 \\
\hline
\end{tabular}

Tablo 2'ye göre Touchstone 2 kitabında en sık kullanılan fiil do $(f=525)$ fiilidir. Bu fiili sirasiyla are $(f=358)$, is $(f=280)$, have $(f=230)$ ve was $(f=167)$ fiilleri izlemektedir. Good $(f=124)$, new $(f=95)$, free $(f=73)$, different $(f=49)$ ve next $(f=46)$ sifatları en sik kullanilan sıfatlardır. En sık kullanılan zarf then $(f=143)$ zarfidır ve bu zarfi sirasiyla really $(f=111)$, too $(f=77)$, here $(f=74)$ ve just $(f=69)$ zarfları takip etmektedir. 
Tablo 3. Mastermind Kitabinda Sik Yer Alan Fiil, Sifat ve Zarflar

\begin{tabular}{|c|c|c|c|c|c|}
\hline Fiil & $f$ & Sifat & $f$ & Zarf & $f$ \\
\hline is & 284 & simple & 50 & there & 71 \\
\hline do & 175 & short & 32 & well & 67 \\
\hline are & 150 & correct & 31 & out & 44 \\
\hline read & 83 & visual & 27 & very & 33 \\
\hline have & 78 & scientific & 26 & again & 31 \\
\hline like & 74 & natural & 24 & then & 27 \\
\hline write & 58 & new & 24 & more & 21 \\
\hline prefer & 46 & first & 23 & also & 21 \\
\hline share & 46 & extra & 23 & most & 19 \\
\hline match & 44 & responsible & 22 & always & 18 \\
\hline be & 42 & online & 21 & now & 17 \\
\hline doing & 39 & great & 21 & usually & 16 \\
\hline go & 39 & favorite & 21 & often & 14 \\
\hline think & 39 & Turkish & 18 & moreover & 13 \\
\hline was & 38 & extreme & 18 & finally & 11 \\
\hline put & 37 & true & 16 & really & 11 \\
\hline listen & 36 & fascinating & 13 & currently & 10 \\
\hline work & 33 & best & 12 & generally & 10 \\
\hline get & 33 & busy & 11 & mostly & 10 \\
\hline understand & 33 & famous & 11 & daily & 9 \\
\hline making & 30 & global & 11 & too & 9 \\
\hline has & 29 & good & 11 & tomorrow & 8 \\
\hline find & 28 & historic & 11 & about & 7 \\
\hline keep & 28 & important & 11 & never & 7 \\
\hline does & 27 & main & 11 & sometimes & 7 \\
\hline add & 26 & old & 11 & today & 7 \\
\hline going & 25 & regular & 11 & together & 6 \\
\hline make & 25 & appropriate & 10 & so & 5 \\
\hline cooking & 24 & sorry & 10 & ever & 5 \\
\hline study & 23 & bad & 9 & nearly & 5 \\
\hline fill & 23 & national & 9 & rather & 5 \\
\hline
\end{tabular}




\begin{tabular}{llllll} 
answer & 22 & daily & 9 & soon & 5 \\
giving & 22 & destructive & 8 & firstly & 4 \\
reading & 22 & different & 8 & forever & 4 \\
want & 22 & easy & 8 & here & 4 \\
following & 21 & false & 8 & later & 4 \\
spoken & 21 & fond & 8 & regularly & 4 \\
did & 20 & inclusive & 8 & abroad & 3 \\
expressing & 20 & oral & 8 & away & 3 \\
prepare & 20 & related & 8 & individually & 3 \\
take & 20 & easier & 8 & just & 3 \\
use & 20 & other & 7 & continuously & 2 \\
using & 20 & specific & 7 & definitely & 2 \\
likes & 20 & sure & 6 & early & 2 \\
complete & 19 & amusing & 6 & easily & 2 \\
mean & 19 & ancient & 6 & especially & 2 \\
express & 18 & awesome & 6 & exactly & 2 \\
including & 18 & exciting & 6 & internationally & 2 \\
look & 17 & free & 6 & irresponsibly & 2 \\
accepting & 16 & healthy & 6 & periodically & 2 \\
\hline
\end{tabular}

Mastermind kitabında ilk sırada is $(f=284)$ fiilinin yer aldığını Tablo 3 göstermektedir. $\mathrm{Bu}$ fiili, do $(f=175)$, are $(f=150)$, read $(f=83)$ ve have $(f=78)$ fiilleri izlemektedir. En sik kullanilan sifatlar simple $(f=50)$, short $(f=32)$, correct $(f=31)$, visual $(f=27)$ ve scientific $(f=26)$ sifatlarıdır. En sik kullanılan zarf there $(f=71)$ zarfiyken well $(f=67)$, very $(f=33)$, again $(f=31)$ ve then $(f=27)$ sik kullanılan diğer zarflardır.

Tablo 4. More \& More Kitabında Sik Yer Alan Fiil, Slfat ve Zarflar

\begin{tabular}{llllll}
\hline Fiil & $\boldsymbol{f}$ & Sıfat & $\boldsymbol{f}$ & Zarf & $\boldsymbol{f}$ \\
\hline is & 510 & correct & 67 & there & 85 \\
do & 366 & great & 66 & usually & 85 \\
have & 248 & best & 51 & always & 69 \\
are & 206 & new & 49 & more & 60 \\
like & 152 & good & 41 & most & 55 \\
go & 120 & social & 41 & very & 53
\end{tabular}


A. Güdücü ve F. Güngör/ Pamukkale Üniversitesi Eğitim Fakültesi Dergisi, 54, 130-157, 2022

be 114

other

40

too

prefer

110

first

35

now 39

think

109

important

35

often

read

104

online

34

also

was

99

exciting

30

really

34

use

74

true

29

tomorrow

33

has

73

favorite

28

rather

31

want

afraid

28

ever

love

70

extreme

never

take

68

popular

27

then

make

64

last

25

first

26

does

61

false

24

again

24

see

60

write

58

hot

sometimes

24

get

help

55

going

52

different

21

as

23

free

20

about

21

join

49

possible

20

together

21

match

46

doing

42

put

42

fill

40

big

19

well

14

old

19

soon

14

better

18

finally

13

natural

18

still

responsible

18

so

9

did

39

dangerous

17

much

9

complete

famous

17

today

9

try

delicious

16

rarely

9

cultural

15

yesterday

9

following $\quad 35$

entertaining

15

alone

8

need

33

share

33

say

32

ancient

14

lot

7

beautiful

14

only

7

classical

14

else

7

leave

31

buy

31

interested

14

later

6

look

31

past

13

mostly

6

shopping

31

busy

13

regularly

6

cool

13

down

5




\begin{tabular}{llllll} 
watch & 31 & large & 13 & currently & 5 \\
add & 29 & scientific & 13 & definitely & 5 \\
visit & 29 & favourite & 12 & far & 5 \\
cook & 28 & historic & 12 & just & 5 \\
am & 27 & nice & 12 & abroad & 4 \\
come & 27 & traditional & 12 & away & 4 \\
feel & 27 & next & 11 & generally & 4 \\
shows & 27 & sorry & 11 & here & 4 \\
mean & 26 & black & 11 & nowadays & 4 \\
wants & 26 & available & 11 & probably & 4 \\
been & 25 & easy & 11 & slowly & 4 \\
\hline
\end{tabular}

Tablo 4'e göre More \& More kitabında en sık kullanılan fiil is $(f=510)$ fiilidir. S1klık bilgileri dikkate alındığında $d o(f=366)$, have $(f=248)$, are $(f=206)$ ve like $(\mathrm{f}=152)$ fiilleri en sik kullanılan fiiller arasındadir. Correct $(f=67)$, great $(f=66)$, best $(f=51)$, new $(f=49)$ sıfatları sık kullanılan sıfatlardır. More \& More kitabında en sık kullanılan zarf there $(f=85)$ zarfidir. Bu zarfi sirasiyla usually $(f=85)$, always $(f=69)$, more $(f=60)$ ve most $(f=55)$ zarfları izlemektedir.

Tablo 5. Marathon Plus Kitabında Sik Yer Alan Fiil, Sifat ve Zarflar

\begin{tabular}{llllll}
\hline Fiil & $\boldsymbol{f}$ & Sifat & $\boldsymbol{f}$ & Zarf & $\boldsymbol{f}$ \\
\hline is & 524 & correct & 77 & there & 138 \\
do & 401 & great & 54 & then & 72 \\
are & 233 & social & 43 & always & 62 \\
have & 206 & online & 41 & very & 59 \\
like & 160 & good & 36 & too & 49 \\
want & 124 & best & 33 & never & 47 \\
go & 115 & true & 32 & also & 41 \\
be & 103 & different & 31 & usually & 33 \\
going & 94 & favorite & 30 & really & 32 \\
prefer & 82 & new & 30 & rather & 31 \\
was & 81 & important & 27 & now & 30 \\
choose & 79 & last & 27 & together & 29 \\
doing & 79 & dangerous & 25 & more & 28
\end{tabular}




\begin{tabular}{|c|c|c|c|c|}
\hline write & 74 & interested & 25 & tomorrow \\
\hline make & 71 & sorry & 24 & most \\
\hline take & 70 & simple & 24 & tonight \\
\hline does & 69 & popular & 23 & often \\
\hline think & 69 & other & 22 & so \\
\hline say & 65 & hot & 22 & sometimes \\
\hline read & 64 & old & 21 & first \\
\hline see & 63 & responsible & 20 & later \\
\hline use & 63 & false & 19 & here \\
\hline love & 58 & famous & 18 & sure \\
\hline match & 57 & first & 17 & today \\
\hline will & 57 & traditional & 17 & yesterday \\
\hline put & 53 & natural & 16 & when \\
\hline has & 52 & boring & 15 & again \\
\hline did & 51 & busy & 15 & well \\
\hline get & 50 & free & 15 & soon \\
\hline work & 47 & amazing & 14 & finally \\
\hline fill & 44 & big & 14 & rarely \\
\hline know & 44 & extreme & 14 & ago \\
\hline tell & 43 & historic & 14 & just \\
\hline making & 42 & interesting & 14 & ever \\
\hline come & 40 & fascinating & 13 & twice \\
\hline listen & 40 & necessary & 13 & less \\
\hline answer & 38 & tasty & 13 & definitely \\
\hline try & 36 & easy & 13 & once \\
\hline enjoy & 35 & fun & 12 & about \\
\hline help & 34 & afraid & 12 & probably \\
\hline learn & 33 & possible & 12 & next \\
\hline find & 32 & small & 12 & easily \\
\hline talking & 32 & clean & 11 & seldom \\
\hline call & 30 & late & 11 & much \\
\hline need & 30 & better & 11 & immediately \\
\hline gone & 30 & awesome & 11 & regularly \\
\hline
\end{tabular}


join 30 entertaining 11 long

using 30 exciting 11 actually 4

add 29

same 10

almost 4

complete

28 past

10 constantly

4

Tablo 5'te, is $(f=524)$, do $(f=401)$, are $(f=233)$, have $(f=206)$ ve like $(f=160)$ fiilleri s1k kullanılan fiillerdir. S1k kullanılan sifatlar correct $(f=77)$, great $(f=54)$, social $(f=43)$, online $(f=41)$ ve $\operatorname{good}(f=36)$ sifatlaridir. There $(f=138)$, then $(f=72)$, always $(f=62)$, very $(f=59)$ s1k kullanılan zarflardır.

\section{Kelime Seviyelerinin CEFR'ye Göre Değerlendirilmesi}

Şekil 1'e göre Upswing English kitabında A1 seviyesindeki kelimelerin oran1 \%23.03 ve A2 seviyesindeki kelimelerin oranı \%19.34'tür. Bu oran Touchstone 2 kitabında A1 için \%26.84 ve A2 için \%23.45 şeklindedir. Mastermind kitabındaki kelimelerin \%22.82'si A1 seviyesinde, \%18.75'i A2 seviyesinde yer almaktadır. More \& More kitabında A1 seviyesindeki kelimelerin oranı \%15.65, A2 seviyesindeki kelimelerin oran1 \%13.85'tir. Marathon Plus kitabında A1 seviyesindeki kelimelerin oranı \%19.99, A2 seviyesindeki kelimelerin oranı $\% 16.31$ 'dir.

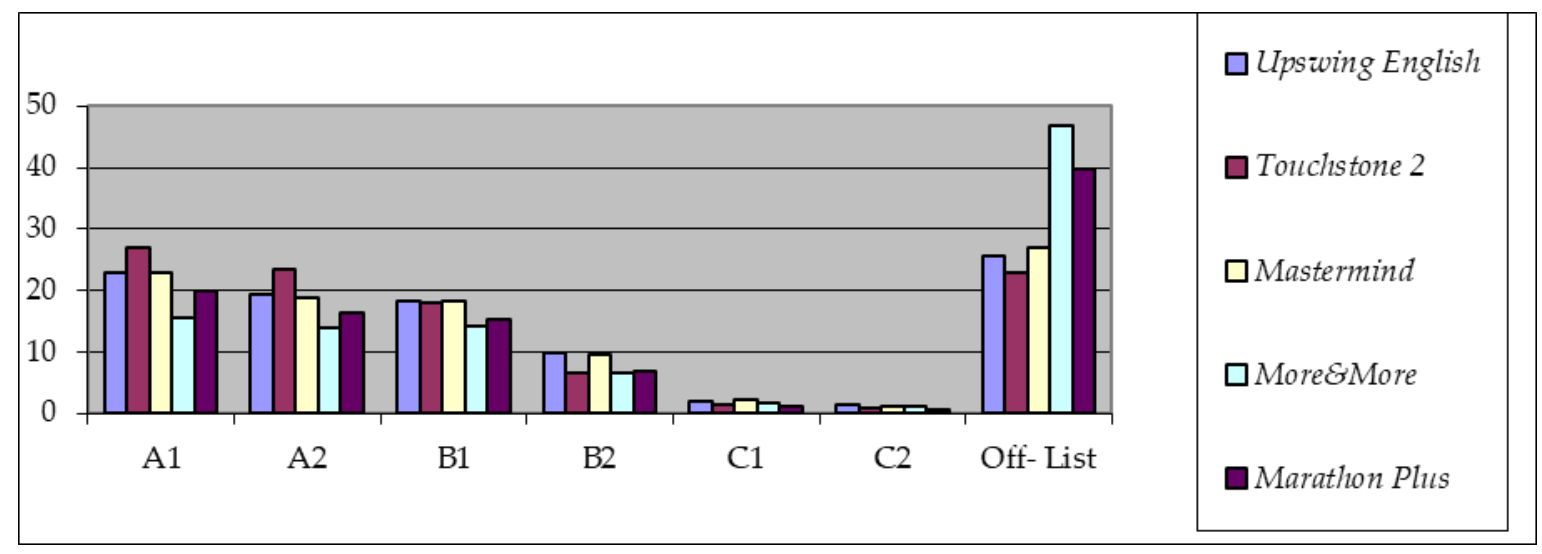

Şekil 1. Kelimelerin CEFR'ye göre seviyelerinin dĕgerlendirilmesi

Upswing English kitabında a, all, examples gibi kelimeler A1 seviyesinde yer alırken ago, build, jump kelimeleri A2 seviyesindedir. Touchstone 2 kitabında A1 seviyesinde dad, minute, snow ve A2 seviyesinde corner, north, opera gibi kelimeler bulunur. Mastermind kitabında about, kitchen, sandwich kelimeleri A1 seviyesinde; add, magazines, should kelimeleri A2 seviyesindedir. More \& More kitabında afternoon, eyes, family kelimeleri A1 seviyesinde; accident, call, lucky A2 seviyesindedir. Marathon Plus kitabinda ise butter, 
now, car gibi kelimeler A1 seviyesinde; actually, empty, library kelimeleri A2 seviyesindedir.

\section{Kelime Seviyelerinin BNC ve COCA’ya Göre Değerlendirilmesi}

BNC ve COCA'ya göre yapılan analizlerin sonuçları karşılaştırılmış ve elde edilen bu sonuçlar Tablo 6'da sunulmuştur. Günlük hayatta iletişim için kritik eşik olarak görülen en sık kullanılan 2000 kelimenin önemi vurgulayan daha önceki çalışmalar (Jahan ve diğerleri, 2019, s. 14; Karadağ, 2019, s. 767 ve Thornbury, 2002, s. 21) göz önünde bulundurularak ders kitaplarında en sik kullanılan 2000 kelime, BNC ve COCA'da en sik kullanılan 2000 kelime ile karşılaştırılmıştır.

Tablo 6. Kelime Seviyelerinin BNC ve COCA'ya Göre Değerlendirilmesi

\begin{tabular}{|c|c|c|c|c|c|c|c|}
\hline & & \multicolumn{3}{|c|}{ İngiliz Ulusal Derlemi (BNC) } & \multicolumn{3}{|c|}{$\begin{array}{c}\text { Çağdaş Amerikan İngilizcesi } \\
\text { Derlemi (COCA) }\end{array}$} \\
\hline & & \multirow{3}{*}{$\begin{array}{l}\text { Kelime } \\
\text { Sayıs1 }\end{array}$} & \multirow{2}{*}{$\begin{array}{l}\text { Kelime } \\
\text { Say1s1 }\end{array}$} & \multirow{3}{*}{$\begin{array}{l}\text { Toplam } \\
\text { Oran }(\%)\end{array}$} & \multirow{3}{*}{$\begin{array}{l}\text { Kelime } \\
\text { Sayıs1 }\end{array}$} & \multirow{3}{*}{$\begin{array}{l}\text { Kelime } \\
\text { Sayıs1 } \\
\text { Oranı (\%) }\end{array}$} & \multirow{3}{*}{$\begin{array}{l}\text { Toplam } \\
\text { Oran }(\%)\end{array}$} \\
\hline & & & & & & & \\
\hline & & & Oranı $(\%)$ & & & & \\
\hline & Liste & 488 & 14.10 & 14.1 & 488 & 14.10 & 14.1 \\
\hline Upswing & Diş1 & & & & & & \\
\hline \multirow[t]{2}{*}{ English } & $0-1 \mathrm{~K}$ & 646 & 18.67 & 32.8 & 681 & 19.68 & 33.8 \\
\hline & $1-2 \mathrm{~K}$ & 419 & 12.11 & 44.9 & 439 & 12.69 & 46.5 \\
\hline \multirow{4}{*}{$\begin{array}{l}\text { Touchstone } \\
2\end{array}$} & Liste & 342 & 11.49 & 11.5 & 342 & 11.49 & 11.5 \\
\hline & D1ş1 & & & & & & \\
\hline & $0-1 \mathrm{~K}$ & 612 & 20.56 & 32.0 & 634 & 21.30 & 32.8 \\
\hline & $1-2 \mathrm{~K}$ & 361 & 12.13 & 44.2 & 421 & 14.14 & 46.9 \\
\hline \multirow{4}{*}{ Mastermind } & Liste & 506 & 16.47 & 16.5 & 506 & 16.47 & 16.5 \\
\hline & Diş1 & & & & & & \\
\hline & $0-1 \mathrm{~K}$ & 591 & 19.24 & 35.7 & 609 & 19.82 & 36.3 \\
\hline & $1-2 \mathrm{~K}$ & 347 & 11.30 & 47.0 & 373 & 12.14 & 48.4 \\
\hline More\&More & $\begin{array}{l}\text { Liste } \\
\text { Diş1 }\end{array}$ & 1996 & 38.19 & 38.2 & 1996 & 38.19 & 38.2 \\
\hline
\end{tabular}




\begin{tabular}{lccccccc} 
& $0-1 \mathrm{~K}$ & 662 & 12.67 & 50.9 & 667 & 12.76 & 50.9 \\
& $1-2 \mathrm{~K}$ & 415 & 7.94 & 58.8 & 469 & 8.97 & 59.9 \\
\hline \multirow{2}{*}{$\begin{array}{l}\text { Marathon } \\
\text { Liste }\end{array}$} & 1298 & 31.41 & 31.4 & 1298 & 31.41 & 31.4 \\
& Diş1 & & & & & & \\
& $0-1 \mathrm{~K}$ & 641 & 15.51 & 46.9 & 664 & 16.07 & 47.5 \\
& $1-2 \mathrm{~K}$ & 390 & 9.44 & 56.4 & 425 & 10.28 & 57.8 \\
\hline
\end{tabular}

Tablo 6, Upswing English kitabının BNC ve COCA'da en s1k kullanılan 1000 kelimenin sırasıyla \%18.67'sini ve \%19.68'ini kapsadığı göstermektedir. Bu oranlar, Touchstone 2 kitabında BNC için \%20.56 ve COCA için \%21.30'dur. Mastermind kitabı BNC ve COCA'daki en sık kullanılan 1000 kelimenin sırasıla \%19.24'ünü ve \%19.82'ini kapsıyorken bu oranlar More \& More kitabında BNC için \%12.67 ve COCA için \%12.76'dır. Marathon Plus kitabı BNC ve COCA'daki en sık kullanılan 1000 kelimenin sirasıyla \%15.5'ini ve \%16.07'sini kapsamaktadır. İkinci en sık kullanılan 1000 kelimeye gelindiğinde, Upswing English kitabı BNC ve COCA'nın sırasıly \%12.11'ini ve \%12.69'unu kapsamaktadır. Bu oranlar, Touchstone 2 kitabında BNC için \%12.13, COCA için \%14.14'tür. Mastermind kitabı BNC ve COCA'da en sık kullanılan ikinci 1000 kelimenin sirasiyla \%11.30'unu ve \%12.14'ünü kapsiyorken bu oranlar More \& More kitabında BNC için\%7.94, COCA için \% 8.97'dir. Son olarak, Marathon Plus kitabı BNC ve COCA'da en s1k kullanılan ikinci 1000 kelimenin sirasıly \%9.44'ünü ve \%10.28'ini kapsamaktadır.

Kitaplar BNC'ye göre değerlendirildiğinde, Upswing English kitabındaki the, you, for, answer, understanding kelimeleri ilk 2000 kelime listesindedir. Diğer kitaplardaki örnekler ise şunlardır: Touchstone 2 kitabında and, a, I, shows, answer; Mastermind kitabinda the, her, to, competition, medical; More \& More kitabinda I, and, the, extra, speak ve Marathon Plus kitabında the, and, so, glass, bill kelimeleridir

COCA'ya göre değerlendirildiğinde Upswing English kitabında I, good, through, source, edge; Touchstone 2 kitabinda your, some, player, fell, trip; Mastermind kitabinda person, game, travel, manner, smart; More\&More kitabinda the, are, said, sister, access; Marathon Plus kitabında I, way, yeah, access, gas kelimeleri en sık kullanılan 2000 kelime listesindedir. 


\section{Kelime Seviyelerinin AWL'ye Göre Değerlendirilmesi}

AWL göz önüne alınarak elde edilen bulgular Tablo 7'de sunulmuştur.

Tablo 7. Kelime Seviyelerinin AWL'ye Göre Dĕgerlendirilmesi

\begin{tabular}{lll}
\hline & Liste & Kelime Saylsl ve Oranı (\%) \\
\hline Upswing English & AWL Toplam & $238(6.88)$ \\
Touchstone 2 & AWL Toplam & $156(5.24)$ \\
Mastermind & AWL Toplam & $197(6.41)$ \\
More\&More & AWL Toplam & $246(4.71)$ \\
Marathon Plus & AWL Toplam & $196(4.74)$ \\
\hline
\end{tabular}

Tablo 7'ye göre Upswing English kitabında yer alan kelimelerin AWL'deki oran1 \%6.88'dir. AWL kelimelerinin oran1, Touchstone 2 kitabinda \%5.24, Mastermind kitabinda \%6.41, More \& More kitabında \%4.71 ve Marathon Plus kitabında \%4.74 şeklindedir. More \& More, AWL listesinden en fazla kelime içeren kitap olmasına rağmen her kitaptaki toplam kelime sayısından dolayı bu kitaptaki oran nispeten düşük kalmıştır.

\section{Tartışma}

Ülkemizde, okullarda İngilizce dersi ikinci sınıftan itibaren başlamasına (MEB, 2013, ss. II) rağmen dil öğretiminde ve dil öğrenmede istenilen düzeye ulaşılamamıştır (Aktaş, s. 45; Coşkun-Demirpolat, 2015, s. 10). Bunun bir nedeni, yabancı dil ders kitaplarında nadir kullanılan kelime öğelerinin ve özgün olmayan okuma ve dinleme metinlerinin seçilmiş olmasıdır (Coskun-Demirpolat, 2015, s. 15). Bu yüzden, ders kitaplarının ana dil konuşurlarından elde edilen derlem verilerine dayanarak hazırlanması gerekmektedir. Böylelikle, kelimelerin kullanım sıklıkları bilgisine ulaşılabilir ve dil öğrenimi ve öğretiminde sık kullanılan kelimelerin üzerinde durulması sağlanabilir. Bu amaçla, bu araştırmadaki kitaplardan oluşturulan derlemlerde yer alan kelime sıklığı bilgisi ile referans derlemler ve kelime listesi ile karşılaştırılmıştır. İlk olarak, sık kullanılan 50 fiil, sıfat ve zarf belirlenmiştir. Ortaya çıkan sonuçlar değerlendirildiğinde, en sık kullanılan fiillerin $d o$, is, are ve have fiilleri olduğu göze çarpmaktadır. Upswing English kitabında, do, is, are, have fiillerinin kullanım sıklığı sırasıyla 296, 246, 164 ve 140’tır. Touchstone 2 kitabında, do, is are ve have fiillerinin kullanım sıklığı sirasıyla 525, 280, 358 ve 230'dur. Diğer kitaplar içinde bu sonuçlar benzer şekildedir. Bu yüksek kullanım sıklığı, bu fiillerin ana fiil olarak kullanılmalarının yanı sıra yardımcı fiil olarakta kullanılmaları ile ilişkilidir. Bu fiillerin dışında, kitaplarda en sık kullanılan fiiller; like, write, use, read, go, make, listen, was, 
going, get, prefer, share, match, be, think ve want fiilleridir. Catalan ve Francisco (2008) s1k kullanılan kelimelerin öğrencilerin yapacağı aktiviteleri gösteren read, write, listen ve complete gibi kelimeler olduğunu belirtmişlerdir. $\mathrm{Bu}$ bağlamda, write, read ve listen gibi kelimeler, araştırmadaki kitaplarda bulunan alıştırmalarda öğrenciye yönerge vermede kullanılmıştır. Sıklık listelerindeki en sık kullanılan on sıfat göz önüne alındığında, devlet okullarında kullanılan Upswing English ve Mastermind kitab1 short, correct ve natural gibi ortak kelimelere sahiptir. MEB tarafından dağıtımı yapılan her iki kitapta, sık kullanılan on sıfat içerisinde benzer sayıda sıfat bulunması beklenmesine rağmen Upswing English ve Mastermind kitaplarındaki kelime kapsamı benzer değildir. Derlem temele alınarak hazırlanmış olan Touchstone 2 kitabında en sık kullanılan ilk on sıfata bakıldığında sadece dört sıfatın (great, good, different ve new) diğer dört kitabın en sık kullanılan on sıfatı içerisinde yer aldığı görülmektedir. Ancak, Touchstone 2 kitabında bu sıfatların kullanım sıklıkları, diğer kitaplara göre çoğunlukla daha fazladır. More \& More ve Marathon Plus kitapları Upswing English ve Mastermind ile uyumlu hazırlanmış kitaplardır. Bu nedenle, bu kitaplardaki sıfatların ve bu sıfatların kullanım sıklıklarının Upswing English ve Mastermind ile benzerlik göstermesi olası bir durumdur. Araştırma sonucu, correct, great, new, good, social, first, favorite ve different gibi sıfatların Upswing English, Mastermind, More \& More ve Marathon Plus kitaplarındaki en sık kullanılan on sıfat içerisinde olduğunu ortaya çıkarmıştır.

Nordlund ve Norberg'in (2020) belirttiği gibi dil edinimi için gerekli olan kelime bilgisine sahip olabilmek için dil öğrenen kişilerin yeni kelimeler ile sıklıkla karşılaşmaları gerekmektedir. Oysa her kelime günlük hayatta aynı sıklıkta kullanılmamaktadır. Bu nedenle, derlemlerde ya da kelime listelerinde yer alan sık kullanılan kelimeleri öğrenmek için kelimelerin tekrar edilmesi son derece önemlidir (Nation, 2001). Thornbury'e (2002) göre bir kelimeyle belirli zaman aralıkları içinde en az yedi kez karşılaşılırsa akılda tutulma olasılığı artmaktadır. Bir kelime ile sekiz ya da daha fazla sayıda karşılaşıldığında öğrenilebilir (Horst, Cobb ve Meara, 1998). Örneğin, Upswing English kitabında 103 kez write fiili ile karşılaşan bir öğrenci, aynı fiil ile More \& More kitabında 58 kez karşılaşmaktadır. Aynı şekilde, good sıfatı ile Touchstone 2 kitabında 124 kez karşılaşmaktayken Mastermind kitabında 11 kez karşılaşmaktadır. Aynı kelimelerin farklı sayılarda tekrar edildiği göz önünde bulundurulduğunda daha fazla tekrar edilen kitaptaki kelimenin öğrenilmesinin tekrar sayısının artması nedeniyle daha kolay olacağı sonucu çıkarılabilir. 
Araştırmada, kitaplarda yer alan kelimeler CEFR'ye göre de değerlendirilmiştir. MEB'e (2018a) göre, Upswing English ve Mastermind kitapları A2 seviyesine denk gelmektedir. $\mathrm{Bu}$ ders kitaplarına paralel hazırlanan More\&More ve Marathon Plus kitaplarının da A2 seviyesinde olduğu düşünülmektedir. Touchstone Avrupa Dilleri için Ortak Başvuru Metni Rehberi’nde (2013) A2 seviyesinde olduğu belirtilen Touchstone 2 kitab1 yapılan analizler sonucu \%23.45 oran ile A2 seviyesinde en yüksek kelime oranına sahiptir. Toplam oranlar, Touchstone 2 kitabının Temel Kullanıcı Düzeyinde (A1 ve A2) yer alan kelimeleri analiz edilen diğer kitaplar arasında en daha yüksek oranda $(\% 50.3)$ kapsadığını göstermektedir. Upswing English kitabı için bu oran \%42.4, Mastermind kitab1 için \%41.6, More \& More kitabı için \%29.5 ve Marathon Plus kitabı için bu oran \%36.3'tür. Alexiou, Mattheoudakis, Saratsli ve Vagenas (2019) çalışmaları sonucunda, A1 seviyesindeki kitapların bu seviyede yer alan kelimeleri içerdiğini belirtmişlerdir. $\mathrm{Bu}$ nedenle, A2 seviyesindeki ders kitaplarının A1 ve A2 seviyesindeki kelime öğelerini içermesi beklenmektedir. Arslan ve Erarslan (2019) Mastermind kitabındaki kelime aktivitelerinde yer alan 270 kelimenin 28 tanesinin (\%10.37) A1 seviyesinde, 49 tanesinin (\%18.14) A2 seviyesinde yer aldığını ve Temel Kullanıcı Düzeyindeki kelimelerin oranının \%28.51'lik bir oranla düşük düzeyde yer aldığını bulmuşlardır. Alexiou ve diğerleri’nin (2019) çalışmasında A1 seviyesindeki kelimelerin kapsanma oranının ilk kitapta \%61.85 ve ikinci kitapta \%60.21 olduğu göz önünde bulundurulduğunda, bu araştırmada Temel Kullanıcı Düzeyi için beklenen oranın \%50'nin üzerinde olması beklenmektedir. Toplam oranlar dikkate alındığında More \& More ve Marathon Plus dışındaki kitaplar \%50 oranına yakınlaşmışlardır. Bu durumda, ders kitaplarının A2 seviyesine yakın olduğu düşünülebilir ancak bu araştırmada ders kitaplarının Temel Kullanıcı Düzeyinde sahip olduğu oranlar nispeten düşük seviyededir. Arslan ve Erarslan (2019) çalışmasında olduğu gibi bu araştırmadaki ders kitaplarının Temel Kullanıcı Düzeyindeki kelime oranlarının nispeten düşük kalmasından dolayı \%50'den daha fazla bir orana sahip Touchstone 2 kitabı dışındaki ders kitapları kelime seçimi kriterlerini gözden geçirip revize etmelidir.

A2 seviyesinde sahip olunması gereken kelime sayıs1 1500 ile 2000 kelime arasındadır (Milton ve Alexiou, 2009; Van Ek ve Trim, 1990). Bu yüzden, araştırmadaki ders kitaplarının BNC ve COCA'daki en sık kullanılan 2000 kelimeyi içermesi beklenmektedir. Ancak, bulgular kısmında belirtildiği üzere bu oranlar nispeten düşük seviyededir. Liste dışı kalan kelimelerin hem BNC hem de COCA için oranları, Upswing English kitabında \%14.10, Touchstone 2 kitabında \%11.49, Mastermind kitabında \%16.47, 
More \& More kitabında \%38.19 ve Marathon Plus kitabında \%31.41 şeklindedir. Baydal'ın (2016, s. 104) çalışmasında, liste dışı kalan kelimelerin oranının (\%12.9) olması ve ikinci 1000 kelime içerisindeki kelimelerin oranının (\%9.10) düşük olması nedeniyle Upturn in English 8 kitabının A2 seviyesine uygun olmadığı düşünülmektedir. S1k kullanılan ikinci 1000 kelime iletişim için gerekli olan içerik kelimelerini içermektedir. Baydal'ın (2016) ve Arslan ve Erarslan'ın (2019) çalışmaları gibi çalışmalarda olduğu üzere liste dışı kalan kelime oranlarının yüksek olması ve sık kullanılan ikinci 1000 kelime oranının sık kullanılan ilk 1000 kelime oranından düşük olması nedeniyle bu araştırmadaki kitapların A2 seviyesine uygun olmadığı düşünülmektedir.

Touchstone 2 kitab1, A2 seviyesine diğer kitaplardan daha yüksek oranda (\%50.3) kelime içerdiği için daha uygun görülmektedir. Dahası, Touchstone 2 kitabı A2 seviyesinde diğer kitaplardan daha fazla oranda kelime (\%23.45) içermektedir. Touchstone 2 kitabı BNC ve COCA'nın sık kullanılan ilk 1000 kelime listesinin sirasıly \%20.56'sını ve \%21.30'nu kapsiyorken bu oranlar BNC ve COCA'nın en sık kullanılan ikinci 1000 kelime listesinin \%12.13'ü ve \%14.14'üdür. Bu oranlar ve A2 seviyesi için gerekli olan kelime büyüklüğü düşünüldüğünde, Touchstone 2 kitabının diğer kitaplardan daha fazla en sık kullanılan ilk 1000 ve ikinci 1000 kelimeye sahip olması ve diğer kitaplardan daha az liste dışı kelimenin (\%11.49) bulunması, Touchstone 2 kitabını A2 seviyesine yakınlaştırdığı düşünülmektedir.

Nation'ın (2001, s. 22) vurguladığı gibi “genellikle 2000 kelime seviyesi sık kullanılan kelimeler için en uygun limit olarak belirtilir”. Bir başka ifadeyle, en sık kullanılan 2000 kelimenin bilinmesi dilin anlaşılması için önemli bir eşiktir. Yapılan analizler sonucu, Touchstone 2, BNC'nin sık kullanılan ilk 1000 ve ikinci 1000 kelime listelerinde en yüksek orana (\%20.56) sahip kitaptır. İlk 1000 içerisinde yer alan yer alan kelimelere bakıldığında the, $a, I, y o u$, $i s$, and gibi kelimeler yer almaktadır. Sik kullanılan kelime öğeleri yapısal sözcük olarak işlev gösteren edatlar, zamirler, belirteçler, bağlaçlar, yardımcı fiiller ve ilgeçlerdir (Alexiou ve diğerleri, 2019; Baydal, 2016; Biber, Johansson, Leech, Conrad ve Finegan, 1999). Liste dışı kalan kelimeler çıkartıldığında, BNC sık kullanılan ilk 2000 kelime listesinde Touchstone 2 kitabının en yüksek orana (\%32.69) sahip olduğu bulunmuştur. $\mathrm{Bu}$ kitab1 sirasıyla \%30.78 ile Upswing English, \%30.54 ile Mastermind, \%24.95 ile Marathon Plus ve \%20.61 ile More\&More kitaplar1 takip etmektedir. Önceki çalışmalara bakıldığında, BNC'nin ilk 2000 kelimesi Hajiyeva'nın (2015) çalışmasında \%88.92'lik, Shin ve Chon'un (2011) çalışmasında \%43.3'lük bir oranla 
yüksek düzeyde yer almaktadır. Ancak, bu araştırmada oran tüm kitaplarda \%33’ten düşük bir düzeyde kalmıştır.

COCA'da yer alan liste dışı kelimeler çıkartıldığında, Touchstone 2 kitabı \%35.44 oran ile sık kullanılan 2000 kelime içerisinde en fazla kelime öğesine sahiptir. Bu durum, McCarthy'nin (2004) belirttiği gibi Touchstone yazarlarının günlük hayatta kullanılan kelimeleri belirleyebilmek adına derlemden yararlandıkları düşüncesini de desteklemektedir. $\mathrm{Bu}$ kitab1 sirasiyla \%32.37 ile Upswing English, \%31.96 ile Mastermind, \%26.35 ile Marathon Plus ve \%21.73 ile More \& More kitapları takip etmektedir. Araştırmada yer alan kitaplar, Öztürk ve Çetin'in (2018) çalışmasının aksine bu çalışmada \%43 seviyesine ulaşamamıştır. Öztürk ve Çetin'in (2018) bulduğu oran bu araştırmadakinden yüksek olmasına rağmen ders kitaplarının ve öğretim programlarının sıklık listelerindeki kelimeleri hedeflemediklerini belirtmişlerdir. Bu araştırma Öztürk ve Çetin'in (2018) çalışması ile benzerlikler göstermektedir ve bu araştırmada yer alan ders kitaplarının sıklık bilgisinden yararlanılarak hazırlanması ve revize edilmesi önerilmektedir.

AWL dikkate alındığında, Upswing English kitabı en yüksek orana (\%6.88) sahipken More \& More kitabı en düşük orana (\%4.71) sahiptir. Hajiyeva'nın (2015, s. 136) çalışmasında, ilk 2000 kelime ailesindeki (word families) kelimelerin \%88.92'lik oranla kitaplarda yer almasına rağmen bu oran Akademik Kelime Listesinde \%6.5 şeklindedir. Cao (2018) yükseköğretimde akademik İngilizce eğitimi alan öğrencilerinin kullandıkları kitabı AWL ile karşılaştırmıştır ve Life A2-B1 kitabında bulunan AWL kelimelerinin oranı \%11.01 şeklindedir. Cao (2018) çalışmasına B1 seviyesi kitapları dâhil etmesine rağmen bu oran düşüktür. $\mathrm{Bu}$ yüzden, Cao (2018) ortaya çıkan bu oranın öğrencilerin akademik çalışmalarında başarılı olabilmeleri için yeterli olmadığını ve başarılı olabilmek için öğrencilerin akademik kelimelere daha fazla oranda maruz kalmaları gerektiğini vurgulamıştır. Sekizinci sınıf öğretim programında belirtildiği üzere A2 temel düzey kullanıcıları "basit ifadeleri ve iletişimsel anlamda elzem olan alanlarda (sözgelimi yalın ve kişisel bilgiler, aile bilgileri, alışveriş, yakın çevre ve iş) sıklıkla kullanılan ifadeleri anlayabilir" (MEB, 2018a, s. 82). Bu araştırmadaki ders kitapları genel İngilizceyi öğretmektedir ve öncelikli olarak günlük hayattaki ifadeleri ve örnekleri içermelidirler. Cao'nun (2018) çalışmasının aksine, araştırmadaki ders kitaplarının AWL'den çok sayıda kelimeyi içermesi umulmamaktadır. Ancak, akademik kelimelerin sınırlı sayıda da olsa kelime öğrenimi içine alınması lise eğitimi için iyi bir hazırlık olacaktır (Ünlü, 2012). 


\section{Sonuç}

İkinci dilde yeterli kelime bilgisine sahip olmak iyi bir anlamayı beraberinde getirir (Nation, 1993). Aynı şekilde, kelime bilgisi "okuma ve yazma gibi dil becerilerinin tek öğesidir" (Nation ve Waring, 1997, s. 6) ve sık kullanılan 2000 kelimeyi öğrenmek dinlendiğini anlama ve okuma becerilerini geliştirmektedir (Jahan ve diğerleri, 2019). Fakat, yeterli seviyede kelime bilgisinin olmaması öğrencilerin başarısını sınırlandırmaktadır (Masrai ve Milton (2017). Ortaya çıkan sonuçlar, derlem temelli ve en sık kullanılan 2000 kelime listesinden çok sayıda kelimeyi içeren Touchstone 2 kitabını kullanan öğrencilerin daha fazla kelime öğesini öğrenme olasılığının olduğunu göstermektedir. Araştırmadaki analizlerdeki sıklık ve çeşitlilik faktörleri (Nunan, 1991) göz önüne alındığında, öğrencilerin ders kitaplarındaki kelimeleri daha kolay öğrenmelerine yardımcı olunabilir. Dolayısıyla, öğrencilerin öğretim programının içeriğini ders kitapları yoluyla aldığı (Cunningsworth, 1995) gerçeği göz önünde bulundurularak öğretim programı ve ders kitabı tasarımlarında kelime sıklığı listeleri kullanılabilir. Bundan dolayı, derlem çalışmaları öğretim programı geliştirmede, ders kitabı tasarımında ve sözlük oluşturmada önemli bir rol oynamaktadır (Aijmer, 2009).

O'Keeffe ve diğerleri (2007, s. 32) oluşturdukları on milyon kelimelik derlemin \%80'nin sık kullanılan 2000 kelimeyi içerdiğini bulmuştur. Bu yüzden, derlemde yer alan ilk 2000 kelimenin ders kitaplarına dâhil edilmesi birçok çalışmanın (Nation ve Waring, 1997, s. 239; Nordlund ve Norberg, 2020; Thornbury, 2002, s. 21) kabul ettiği gibi A2 seviyesinde yer alan çoğu kelimeyi kapsayacaktır. Buna ek olarak, bu araştırmadaki ders kitapları genel İngilizceyi öğretmek için kullanılmasına rağmen sınırlı sayıda da olsa AWL'den akademik kelimelerin katılması lise eğitimi için iyi bir hazırlık olacaktır (Ünlü, 2012). Bu araştırmanın sonucunda ortaya çıkan bulgular yabancı dil öğretim müfredatı tasarlayanlar, materyal tasarımcıları, ders kitabı yazarları, öğretmenler ve öğrenciler için önemli bir kaynak sayılabilir. Bu bağlamda, yabancı dil öğretim programı hazırlanırken, öğretim programı geliştirenlerin derlemden elde edilen özgün dil örneklerini ve kelime sıklığı bilgisini dikkate almaları gerektiği düşünülmektedir ve bu doğrultuda öğretim programları tasarlanabilir. Derlem temelli materyaller, yazma alanında tam olarak uzmanlaşmamış kişilerin seviyelerine uygun kelime öğelerini öğrenmelerine yardımcı olabilir (Güngör ve Uysal, 2020). Bu ve benzer araştırmalardaki verileri kullanarak, MEB devlet okulları için kitap hazırlayan yayınevlerine dâhil etmeleri gereken temel kelime listeleri ve kelime ögeleri hakkında tavsiye kararlar yayımlayabilir. Kitap yazarları kelime 
sıklığ1 bilgisini göz önünde bulundurabilirler ve ders kitaplarındaki metinlerde ve aktivitelerde derlem verilerinden yararlanabilirler. $\mathrm{Bu}$ araştırmadaki derlem verileri ve kelime listeleri dikkate alınarak sınıf içerisinde VYÖ aktiviteleri kullanılabilir. 2023 Vizyon belgesinde belirtildiği gibi derlem ve sıklık bilgisini içeren mobil teknolojiler sınıflara entegre edilebilir. Materyal tasarlayanlar, derlem içerisinden gerçek hayatta kullanılan dilin örneklerini çıkararak aktiviteler tasarlayabilirler (Krieger, 2003). Bu konuda, mevcut araştırmayı ileriye taşımak amacıyla farklı sınıf seviyelerinde farklı kitaplar için farklı derlemlerin temele alındığı derinlemesine incelemeler yürütülebilir.

Etik Kurul İzin Bilgisi: Yapılan bu çalışmada "Yükseköğretim Kurumları Bilimsel Araştırma ve Yayın Etiği Yönergesi” kapsamında uyulması belirtilen tüm kurallara uyulmuştur. Yönergenin ikinci bölümü olan "Bilimsel Araştırma ve Yayın Etiğine Aykırı Eylemler" başlı̆̆ altında belirtilen eylemlerden hiçbiri gerçekleştirilmemiştir. Bu araştırma derlem analizi olmasi sebebiyle etik kurul izni gerektirmemektedir.

Yazar Çıkar Çatışması Bilgisi: Yazarların beyan edeceği bir çıkar çatışması yoktur.

Yazar Katkısı: Birinci yazar, Abdurrahman Güdücü, literatür taraması, verilerin toplanması, verilerin analizi ve makalenin yazılması aşamasında katkı sağlamıştır. İkinci yazar, Fatih Güngör, araştırmanın fikrinin oluşturulmasında, araştırma yöntemlerinin belirlenmesinde, makalenin gönderiminden önce makalenin yazımı ve gözden geçirilmesinde ve revize edilmesinde katkı sağlamıştır. 


\section{Kaynakça}

Aijmer, K. (2009). Introduction: Corpora and language teaching. In K. Aijmer (Ed.), Corpora and language teaching (pp. 1-10). Amsterdam: John Benjamins.

Aktaş, T. (2004). Yabancı dil öğretiminde iletişimsel yeti. Selçuk Üniversitesi Sosyal Bilimler Enstitüsü Dergisi, 12, 45-57.

Alcaraz, G. (2009). Frequency and functionality: Two keys for L2 coursebooks. International Journal of English Studies, 9(3), 61-72.

Alexiou, T., Mattheoudakis, M. Saratsli, D., \& Vagenas, A. (2019). Words don't come easy: Linguistic analysis of vocabulary in Magic Books. Journal of Applied Linguistics, 32, 25-41. https://doi.org/10.26262/jal.v0i32.7515

Alexiou, T., \& Konstantakis, N. (2009). Lexis for young learners: Are we heading for frequency or just common sense?. Selected Papers on Theoretical and Applied Linguistics, 18, 59-66.

Alhudithi, E. (2017). Corpus-based analysis of English vocabulary input provided in K-12 textbooks used in Saudi Arabia (Doctoral dissertation). Colorado State University.

Anthony, L. (2019). AntConc (3.5.8. Versiyon) [Bilgisayar Yazılımı]. Tokyo, Japonya: Waseda Üniversitesi.

Arslan, A., \& Erarslan, A. (2019). Lexical analysis of a textbook based on the EVP. International Journal of Languages' Education and Teaching, 7(1), 1-12. https://doi.org/10.18298/ijlet.3230

Baydal, D. (2016). A corpus based study on vocabulary of an A2 level English textbook (Yayınlanmamış Yüksek Lisans Tezi). Ondokuz Mayıs Üniversitesi Eğitim Bilimleri Enstitüsü, Samsun.

Biber, D., Johansson, S., Leech, G., Conrad, S. \& Finegan, E. (1999). Longman Grammar of Spoken and Written English. England: Pearson.

Cao, T. H. P. (2018). Vocabulary in EFL textbook: An analysis of "Life A2-B1" coursebook used for Vietnamese tertiary students. Proceedings of the 7th Vietnamese Young Researchers Conference in Education at Hanoi National University of Education, section 3, 548-556. 
Catalan, R. J., \& Francisco, R. M. (2008). Vocabulary input in EFL textbooks. Revista Española De Lingüística Aplicada, 21, 147-165.

Coşkun-Demirpolat, B. (2015). Türkiye'nin yabancı dil öğretimiyle imtihanı sorunlar ve çözüm önerileri. Analiz, 131, 7-19.

Cunningsworth, A. (1995). Choosing your coursebook. Oxford: Heinmann.

Çinar, K. (2015). A Corpus-based approach to Turkish EFL textbook evaluation: Single word and four-word lexical bundle frequency. (Unpublished master dissertation). Yeditepe University Graduate School of Educational Sciences: İstanbul.

Gilquin, G., \& Granger, S. (2010). How can data-driven learning be used in language teaching? In A. O'Keeffe \& M. McCarthy (Eds.), The Routledge handbook of corpus linguistics (pp. 359-370). Abingdon: Routledge.

Guan, X. (2013). A study on the application of data-driven learning in vocabulary teaching and learning in China's EFL class. Journal of Language Teaching and Research, 4(1), 105-112. https://doi.org/10.4304/jltr.4.1.105-112

Güngör, F. (2016). Crosslinguistic analysis of lexical bundles in L1 English, L2 English, and L1 Turkish research articles (Unpublished doctorate dissertation). Gazi Üniversitesi Eğitim Bilimleri Enstitüsü: Ankara.

Güngör, F., \& Uysal, H. H. (2020). Lexical bundle use and crosslinguistic influence in academic texts. Lingua, 242, 102859.

Hajiyeva, K. (2015). A corpus-based lexical analysis of subject-specific university textbooks for English majors. Ampersand, 2, 136-144.

Horst, M., Cobb, T., \& Meara, P. (1998). Beyond a clockwork orange: Acquiring second language vocabulary through reading. Reading in a Foreign Language, 11, 207-223.

Hunston, S. (2002). Corpora in applied linguistics. Cambridge: Cambridge University Press

Jahan, K, Mahmood, M.A., \& Azhar, W. (2019). Lexical analysis of intermediate English coursebooks: A corpus based study. International Journal of Educational Sciences, 24(1-3), 13-22.

Johansson, S. (2009). Some thoughts on corpora and second-language acquisition. In K. Aijmer (Ed.), Corpora and language teaching (pp. 33-44). Amsterdam: John Benjamins. 
Jordan, G., \& Gray, H. (2019). We need to talk about coursebooks. ELT Journal, 73(4), 438446.

Karadağ, Ö. (2019). Neden bir çocuk dili derlemine ihtiyacımız var? Ana Dili Ĕgitimi Dergisi, 7(3), 765-780.

Kayaoğlu, M. N. (2011). A critical apprasial of the language textbook. KEFAD, 12(4), 341356.

Kim, S. S. (2002). A corpus-based analysis of the words in the elementary school English textbooks. English Teaching, 57(3), 253-277.

Kirana, D. P., Basthomi, Y., Isnawati, U. M., \& Fitriani, A. (2018). A corpus-based study of vocabulary as input in EFL text-book: A case in an Indonesian Islamic College. Journal of Applied Linguistics and Language Research, 5(5), 93-104.

Kitao, K. \& Tanaka, S. (2009). Characteristics of Japanese junior high school English textbooks: From the viewpoint of vocabulary and readability. Journal of Culture and Information Science, 4(1), 1-10.

Krieger, D. (2003). Corpus linguistics: What it is and how it can be applied to teaching. The Internet TESL Journal, 9(3).

Leech, G. (2011). Frequency, corpora and language learning. In F. Meunier, S. De Cock, G. Gilquin \& M. Paquot (Eds.), A taste for corpora-in honour of Sylviane Granger (pp. 7-32). Amsterdam: John Benjamins

Masrai, A. \& Milton, J. (2017). Recognition vocabulary knowledge and intelligence as predictors of academic achievement in EFL context. TESOL International Journal, $12(1), 128-142$.

McCarthy, M. (2004). Touchstone from Corpus to Coursebook. Cambridge: Cambridge University Press.

McEnery, T. \& Hardie, A. (2012). Corpus linguistics method, theory, and practice. Cambridge: Cambridge University Press.

McEnery, T. \& Xiao, R. (2010). What corpora can offer in language teaching and learning. In E. Hinkel (Ed.), Handbook of research in second language teaching and learning (pp: 364-380). London\& New York: Routledge. 
McEnery, T., \& Wilson, A. (1997). Teaching and language corpora (TALC). ReCALL, 9(1), $5-14$.

Milton J., Alexiou T. (2009) Vocabulary size and the Common European Framework Of Reference for languages. In B. Richards, M. H. Daller, D. D. Malvern, P. Meara, J. Milton, \& J. Treffers-Daller (Eds.), Vocabulary studies in first and second language acquisition (pp. 194-211). Palgrave Macmillan, London.

Mindt, D. (1996). English corpus linguistics and the foreign langauge teaching syllabus. In J. Thomas \& M. Short (Eds.), Using corpora for language research (pp. 232-247). Harlow: Longman.

Milli Eğitim Bakanlığı. (2013). Illköğretim kurumları (ilkokullar ve ortaokullar) Ingilizce dersi (2,3,4,5,6,7 ve 8. sinıflar) ögretim programı. Ankara: Milli Eğitim Bakanlı̆̆1.

Milli Eğitim Bakanlı̆̆ı. (2018a). İlköğretim Kurumları (İlkokullar ve Ortaokullar) İngilizce Dersi (2,3,4,5,6,7 ve 8. Sinıflar) Öğretim Programı. Ankara: Milli Eğitim Bakanlığı.

Milli Eğitim Bakanlığı. (2018b). Turkey’s education vision 2023. Milli Eğitim Bakanlığı.

Nation, I.S.P. (1993) Vocabulary size, growth and use. In R. Schreuder and B. Weltens (Eds.), The bilingual lexicon (pp. 115-134). Amsterdam/Philadelphia: John Benjamins.

Nation, I.S.P. (2001). Learning vocabulary in another language. Cambridge: Cambridge University Press.

Nation, P., \& Waring, R. (1997). Vocabulary size, text coverage and wordlists. In N. Schmitt \& M. McCarthy (Eds.), Vocabulary: description, acqusition and pedagogy 1 (pp. 6-19). Cambridge: Cambridge University Press.

Nordlund, M. (2016). EFL textbooks for young learners: A comparative analysis of vocabulary. Education Inquiry, 7(1), 27764.

Nordlund, M., \& Norberg, C. (2020). Vocabulary in EFL teaching materials for young learners. International Journal of Language Studies, 14(1), 89-116.

Nunan, D. (1991). Language teaching methodology (Vol. 192). New York: Prentice Hall.

O'Keeffe, A., McCarthy, M., \& Carter, R. (2007). From corpus to classroom: Language use and language teaching. Cambridge University Press. 
Öztürk, M., \& Çetin, K. B. (2018). Lexical component of young learners' English syllabus in Turkey. International Journal of Languages Education, 6(3), 308-316.

Sheldon, L. E. (1988). Evaluating ELT textbooks and materials. ELT Journal, 42(4), 237246.

Shin, D., \& Chon, Y.V. (2011). A Corpus-based Analysis of Curriculum-based Elementary and Secondary English Textbooks. Multimedia Assisted Language Learning, 14(1), 149-175.

Sinclair, J., \& Renouf, A. (1988). A lexical syllabus for language learning. Vocabulary and Language Teaching, 140, 60.

Sun, Y., \& Dang, T. N. Y. (2020). Vocabulary in high-school EFL textbooks: Texts and learner knowledge. System, 93, 102279.

Suna, Y., \& Durmuşçelebi, M. (2013). Türkiye'de yabancı dil öğrenme- öğretme problemine ilişkin yapılan çalışmaların derlemesi. OPUS Türkiye Sosyal Politika ve Çalışma Hayatı Araştırmaları Dergisi, 3(5), 7-24.

Thornbury, S. (2002). How to teach vocabulary. Essex: Pearson Education Limited.

Touchstone CEFR Guide Level 2 (2013). Cambridge University Press: Cambridge.

Turanlı, A. (2004). Yabanc1 dil öğretiminde istenmeyen öğrenci davranışları ve önleyici yönetim yaklaşımları. Eurasian Journal of Educational Research, 17, 31-44.

Ünlü, F. (2012). Loading, distribution, and repetition patterns of the 2000 high frequency words of general English in an EFL coursebook (Yayınlanmamış Yüksek Lisans Tezi). Karadeniz Teknik Üniversitesi Sosyal Bilimler Enstitüsü, Trabzon.

Van Ek, J. A., \& Trim, J. L. M. (1991). Threshold level 1990. Council of Europe.

Wahid, R. (2011). The use of corpus-based techniques in literary analysis: Exploring learners' perceptions. Asiatic, 5 (1), 104-128.

WebLingua (n.d.). Textinspector. https://textinspector.com/workflow

Zimmerman, C. B., \& Schmitt, N. (2005). Lexical questions to guide the teaching and learning of words. The CATESOL Journal, 17(1), 164-170. 